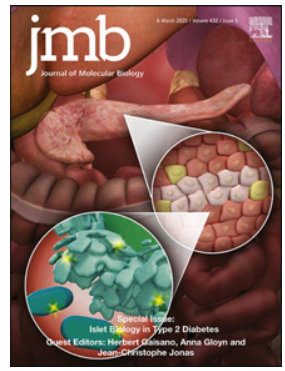

\title{
Breaking Bad and Breaking Good: $\beta$-Cell Autophagy Pathways in Diabetes
}

\author{
Kevin Vivot ${ }^{1,2,3,4, \dagger}$, Adrien Pasquier ${ }^{5, \dagger}$, Alexander Goginashvili ${ }^{6}$ and \\ Romeo Ricci ${ }^{1,2,3,4,7}$,
}

1 - Institut de Génétique et de Biologie Moléculaire et Cellulaire, Illkirch 67404, France

2 - Centre National de la Recherche Scientifique, UMR7104, IIlkirch 67404, France

3 - Institut National de la Santé et de la Recherche Médicale, U964, Illkirch 67404, France

4 - Université de Strasbourg, Strasbourg 67081, France

5 - Telethon Institute of Genetics and Medicine (TIGEM), Pozzuoli, Italy

6 - Ludwig Institute for Cancer Research; Department of Cellular and Molecular Medicine, University of California San Diego,

La Jolla, CA 92093, USA

7 - Laboratoire de Biochimie et de Biologie Moléculaire, Nouvel Hôpital Civil, Strasbourg 67091, France

Correspondence to Alexander Goginashvili and Romeo Ricci: Institut de Génétique et de Biologie Moléculaire et Cellulaire, Illkirch 67404, France. agoginashvili@ucsd.edu, romeo.ricci@igbmc.fr

https://doi.org/10.1016/j.jmb.2019.07.030

\begin{abstract}
For many decades the lysosome has been recognized as the terminal center of cellular waste disposal. Products of lysosomal degradation are either recycled in biosynthetic pathways or are further metabolized to produce energy. As such the lysosome was attributed a rather passive role in cellular metabolism merely transforming bulk material into small metabolites. More recently, however, the emerging evidence has brought the lysosome to the center of nutrient sensing as the organelle that harbors a complex signaling machinery which dynamically and actively regulates cell metabolism.

The pancreatic $\beta$ cell is unique in as much as nutrient sensing is directly coupled to insulin secretion. Importantly, defects in insulin secretion constitute a hallmark in the progression of patients from a state of impaired glucose tolerance to full blown type 2 diabetes (T2D). However, mechanisms linking nutrientdependent lysosomal function to insulin secretion and more generally to $\beta$ cell health have evolved only very recently. This review discusses emerging concepts in macroautophagy and macroautophagy-independent processes of cargo delivery to lysosomes as well as nutrient-dependent lysosomal signaling specifically in the context of $\beta$ cell function in health and disease. Such mechanisms may provide a novel source of therapeutic targets to be exploited in the context of $\beta$ cell failure in diabetes in the near future.
\end{abstract}

() 2019 Elsevier Ltd. All rights reserved.

\section{Introduction}

A milestone in the field of cell biology was the discovery of the lysosome by Christian de Duve [1]. De Duve (who coined the term "lysosome" as well as "autophagy", "phagocytosis" and "endocytosis") [2,3] and coworkers initially observed an unusual behavior of acid phosphatases and other hydrolases in subcellular fractions. They found that their enzymatic activity increased after exposing fractions to detergents, hypotonic media, or other protocols. From these fundamental observations, they concluded that the enzymatic activity was shielded as these hydrolases were likely to be contained in acidified membrane-bound vesicles that disrupted only in response to above treatments. Subsequent electron microscopy experiments in collaboration with Alex Novikoff evidenced the existence of such vesicles, the lysosomes [4]. Cytochemistry confirmed localization of acid phosphatase activity in the lysosome [5]. Loaded with a cocktail of different hydrolases, the lysosome thus constitutes a fundamental 
compartment of the eukaryotic cell in which cellular material of different origin is degraded. In addition, in specialized cells, lysosome-related organelles can also serve as a store of secretory cargo [6].

Lysosomal hydrolases are synthesized in the rough endoplasmic reticulum (RER) and transferred through the Golgi complex to the Trans-Golgi Network (TGN). At the TGN, they are sorted into transport vesicles destined for their delivery to the endosomal/lysosomal compartment. Tagging of most lysosomal hydrolases with mannose-6-phosphate (M6P) in the Golgi complex and its recognition by M6P receptors (M6PRs) in the TGN allows for their proper sorting into these transport carriers. However, trafficking of some lysosomal hydrolases - similar to the transport of lysosomal membrane proteins - occurs independent of the M6PR pathway [7].

Lysosomal delivery of material destined for degradation can occur via distinct pathways depending on where it needs to be transported from (Fig. 1). Extracellular material is internalized from the surface of eukaryotic cells via endocytosis. The mechanisms of different endocytic pathways are discussed in great detail elsewhere $[8,9]$.

The basic process routing intracellular material to lysosomes for digestion is autophagy. To date, four major types of autophagy are distinguished based on the mode of substrate delivery to lysosomes and on specific molecular mediators. Macroautophagy represents a main process removing damaged organelles and unused or aggregated proteins in cells. During macroautophagy in mammalian cells,

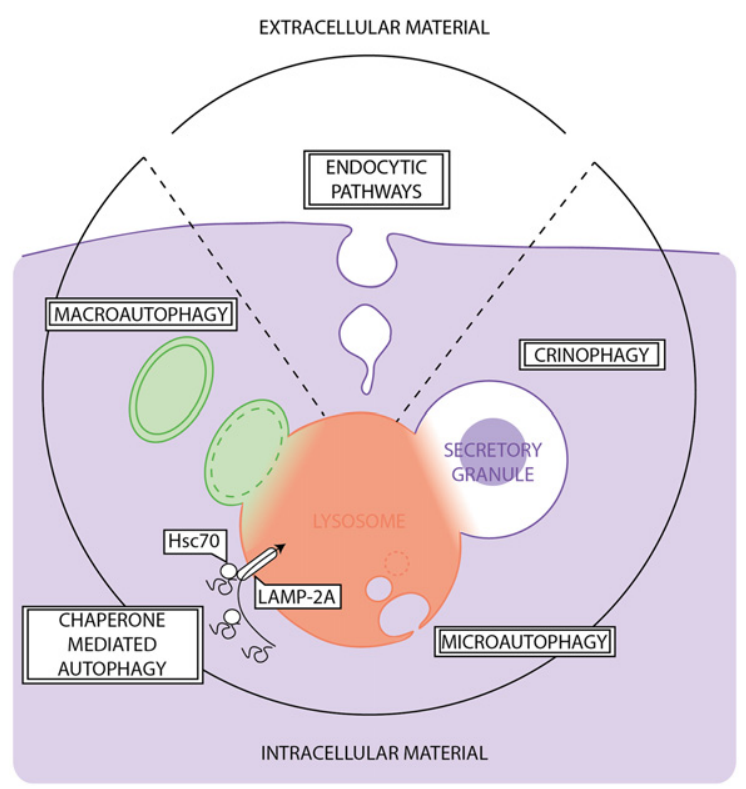

Fig. 1. Overview of major pathways of lysosomal delivery. The lysosome receives extracellular material via endocytic pathways, and intracellular material via macroautophagy, crinophagy, chaperone-mediated autophagy and microautophagy. an isolation membrane (phagophore) is generated from the omegasome at the Endoplasmic Reticulum (ER) and/or mitochondria-associated ER membranes (MAMs). Once released from these sites the double-membrane phagophore engulfs cellular components and forms the autophagosome upon its closure. The Golgi apparatus, plasma membrane, late and recycling endosomes in close proximity of the ER cooperates with the latter to form the phagophore and autophagosome. The fully formed autophagosome in turn fuses with the lysosome (autolysosome), where degradation occurs [10]. While macroautophagy in response to nutrient deprivation degrades substrates in a rather non-selective manner (bulk autophagy), it is also capable to exclusively eliminate specific structures and thus to more tightly regulate cellular metabolism. Selective pathways include for example macroautophagymediated degradation of lipid droplets (lipophagy) or mitochondria (mitophagy). Formation of the autophagosome is controlled by a complex machinery consisting of the autophagy-related (ATG) proteins [11].

As opposed to macroautophagy, microautophagy and chaperone-mediated autophagy do not require autophagosome-mediated delivery of substrates to lysosomes. Microautophagy involves invagination and pinching off of the lysosomal membranes allowing for direct lysosomal uptake of soluble or membranebound material. This leads to formation of an intralysosomal vesicle that is either degraded or opened up to release its contents to the lysosomal milieu [12]. Finally, chaperone-mediated autophagy (CMA) involves recognition of distinct cytoplasmic substrate proteins by the Hsc70 chaperones and binding of the substratechaperone complex to LAMP-2A monomers on lysosomes. Upon oligomerization of LAMP-2A, the substrate protein is translocated into the lysosomal lumen and subsequently degraded [13].

Secretory vesicles can degrade their contents by fusing directly with lysosomes. This autophagic process (termed "crinophagy" by De Duve) has been discovered by Marilyn Farquhar in the anterior pituitary gland in response to inhibition of exocytosis [14]. The molecular mechanisms of crinophagy remain largely unexplored. Only recently, a study investigated mechanisms of developmentally programmed crinophagy in drosophila. They found that fusion of secretory granules with lysosomes occurred independent of ATG proteins involved in macroautophagy but required the tethering complex HOPS (homotypic fusion and protein sorting), the small GTPases Rab2 and Rab7 and a SNAP receptor complex. Degradation of secretory material also relied on proper Uvrag-containing Vps34 and v-ATPase proton pump-dependent lysosomal function [15].

Apart from its predominant role in degradation, it is now widely accepted that lysosomes provide a highly dynamic nutrient-dependent signaling platform. A key sensor of nutrients is the mammalian/ 
mechanistic target of rapamycin (mTOR) complex 1 (mTORC1), first described in yeast $[16,17]$. mTORC1 is recruited to and activated at the lysosome in response to addition of amino acids [18] as well in response to nutrients generated in lysosomes through degradation of cellular material during prolonged starvation [19]. Activation of mTORC1 in turn stimulates cellular growth and proliferation and inhibits macroautophagy. mTORC1 activity also results in stepwise phosphorylation of multiple serine residues of the transcription factor TFEB, a master regulator of lysosomal function and macroautophagy, keeping the latter inactive in the cytoplasm [20]. Amino acid sensing mechanisms converging into lysosomal mTORC1 activity have been subject of intensive research efforts that uncovered a complex lysosomal nutrientdependent signaling machinery [21]. As opposed to mTORC1, AMP-activated protein kinase (AMPK) senses low energy in response to low nutrient availability. Interestingly, AMPK was also reported to be recruited to the lysosomal nutrient sensing complex under low nutrient conditions leading to its activation and induction of autophagy [22].

Hence, the lysosome not only provides a source of basic molecular building blocks and nutrients while degrading cellular material but also harbors a signaling hub that dynamically controls the cell's bioenergetics in response to nutritional cues. This review provides a comprehensive overview about the role of autophagy pathways and lysosomal functions in the pancreatic $\beta$ cell and discusses their links to $\beta$ cell failure in T2D potentially opening novel therapeutic opportunities.

\section{Macroautophagy maintains $\beta$ cell function and protects against $\beta$ cell failure in diabetes}

The process of macroautophagy in the pancreatic $\beta$ cell, especially in regard to diabetes, has been a subject of intensive research efforts. Over the last decade, a great variety of ideas - often contradicting each other - on the activity of macroautophagy and its potential role in diabetes, have gradually transformed into a more unifying (yet still incomplete) picture, according to which macroautophagy initially protects $\beta$ cells against failure and eventually fails to do so in the course of diabetes progression. The expansion of model systems and the progress in the understanding of the molecular mechanisms controlling macroautophagy in the $\beta$ cell had largely contributed to this change. However, we also believe that the discrepancies regarding the role and activity of macroautophagy in $\beta$ cells reflected a general complexity in the interpretation of macroautophagy data, which is discussed in detail in [23]. Here we present a historical perspective of this field and the up-to-date picture, in parallel discussing the common pitfalls in the interpretation of results concerning macroautophagy in $\beta$ cells.

\section{Macroautophagy - The basics}

Extensive genetic studies in the 1990-s (by the groups of Yoshinori Ohsumi, Michael Thumm and Daniel Klionsky) identified the large (more than 30 members) and highly conserved group of autophagy-related genes (ATG) involved in the control of this pathway in yeast [24-28], followed by studies in mammalian models by Yoshinori Ohsumi, Noboru Mizushima, Beth Levine and others [29-32]. We refer here to excellent reviews describing in more details the basic mechanisms of macroautophagy $[33,34]$. Briefly, several subgroups of proteins constitute the "core" of macroautophagy, including three functional modules controlling early stages of macroautophagy - induction and formation of autophagosome: a) Unc-51 like autophagy activating kinase/autophagy-related complex 1 (ULK1/Atg1), an initiator of autophagosome formation, in particular, upon starvation; b) The class III phosphatidylinositol kinase VPS34/Beclin $1 \mathrm{com}-$ plex that controls nucleation end expansion of growing phagophore; c) two ubiquitin-like conjugation systems, the Atg12-Atg5 and Atg8/ microtubule-associated protein 1 light chain 3 (LC3), which are responsible for the elongation of the phagophore and proper formation of autophagosomes.

On a practical note, the expression and the localization of two proteins are most commonly used to address the levels of macroautophagy: LC3, and in particular, its lipidated autophagosome membrane-associated form (designated as LC3-II) [35]; and p62, the protein binding polyubiquitinated protein aggregates, thus mediating their clearance by macroautophagy [36]. Macroautophagy involves the formation of the cargo-containing autophagosomes that subsequently fuse with lysosomes. Quantifying numbers of autophagosomes (using electron microscopy or markers for autophagosomes such as LC3) is thus the most intuitive way to estimate activity of macroautophagy. However, since autophagosomes are subject of lysosomal degradation along with its cargo, they cannot be taken in isolation as a measure of the levels of macroautophagy: for example, an accumulation of autophagosomes would be observed in the case of increased formation of autophagosomes (increased macroautophagy), but also when fusion of autophagosomes with lysosomes and/or degradation of autophagosomes is decreased (thus indicating compromised or blocked macroautophagy). Therefore, additional assays are required, such as addressing the levels of common substrates of macroautophagy (like p62), the ratios between 
autophagosomes and autolysosomes, and measurements of autophagic flux [23].

\section{Macroautophagy is important for $\beta$ cell function}

The tremendous progress in unraveling molecular mechanisms of macroautophagy had allowed to genetically address the role of this pathway in health and disease, including diabetes. A "tour-de-force" approach had been the generation of conditional knockout mice in which the essential macroautophagy genes were specifically deleted in different organs, tissues and cell types [37-40]. Indeed, two pivotal studies, published back-to-back by the groups of Myung-Shik Lee and Hirotaka Watada in 2008, generated mice lacking Atg7 (which product belongs to the Atg12-Atg5 module) in pancreatic $\beta$ cells. Atg $7^{\text {Bcell } \mathrm{KO}}$ mice were alive and indistinguishable in appearance and growth from age-matched control animals up to 1 year of age [41]; and the loss of macroautophagy alone was not sufficient to induce diabetes in these mice $[41,42]$. However, $\operatorname{Atg} 7^{\text {Bcell KO }}$ mice progressively developed glucose intolerance and impaired insulin secretion, especially when fed a high-fat diet [42]. These phenotypes were associated with the deterioration of islet architecture, loss of insulin and accumulation of protein aggregates, strongly indicating that basal macroautophagy is important for $\beta$ cell function. Furthermore, deletion of Atg7 in $\beta$ cells in a genetic model of obesity, leptin-deficient $o b / o b$ mice, led to a severe diabetes, thus suggesting that macroautophagy may serve as a protective mechanism in $\beta$ cells in response to metabolic stress [43].

\section{How does macroautophagy protect against $\beta$ cell failure?}

Damaged organelles and misfolded proteins, frequently forming aggregates - threats constantly faced by the $\beta$ cell that has to control and operate energy-demanding processes such as insulin biosynthesis, trafficking and secretion - represent major targets of macroautophagy (Fig. 2). In fact, important genetic hotspots are in line with a model in which compromised macroautophagy may contribute to $\beta$ cell failure in diabetes. The homeodomain transcription factor $\mathrm{Pdx} 1$, genetic variants of which are associated with both T2D and monogenic diabetes of the young controls mitophagy in $\beta$ cells [44]. Mitophagy is a specific form of macroautophagy responsible for clearance of damaged mitochondria [45]. Mechanistically, Pdx1 mediates E3 ubiquitin ligase Nrdp1-dependent expression of Clec16a, a type 1 diabetes susceptibility gene and important regulator of mitophagy. Pancreas-specific deletion of

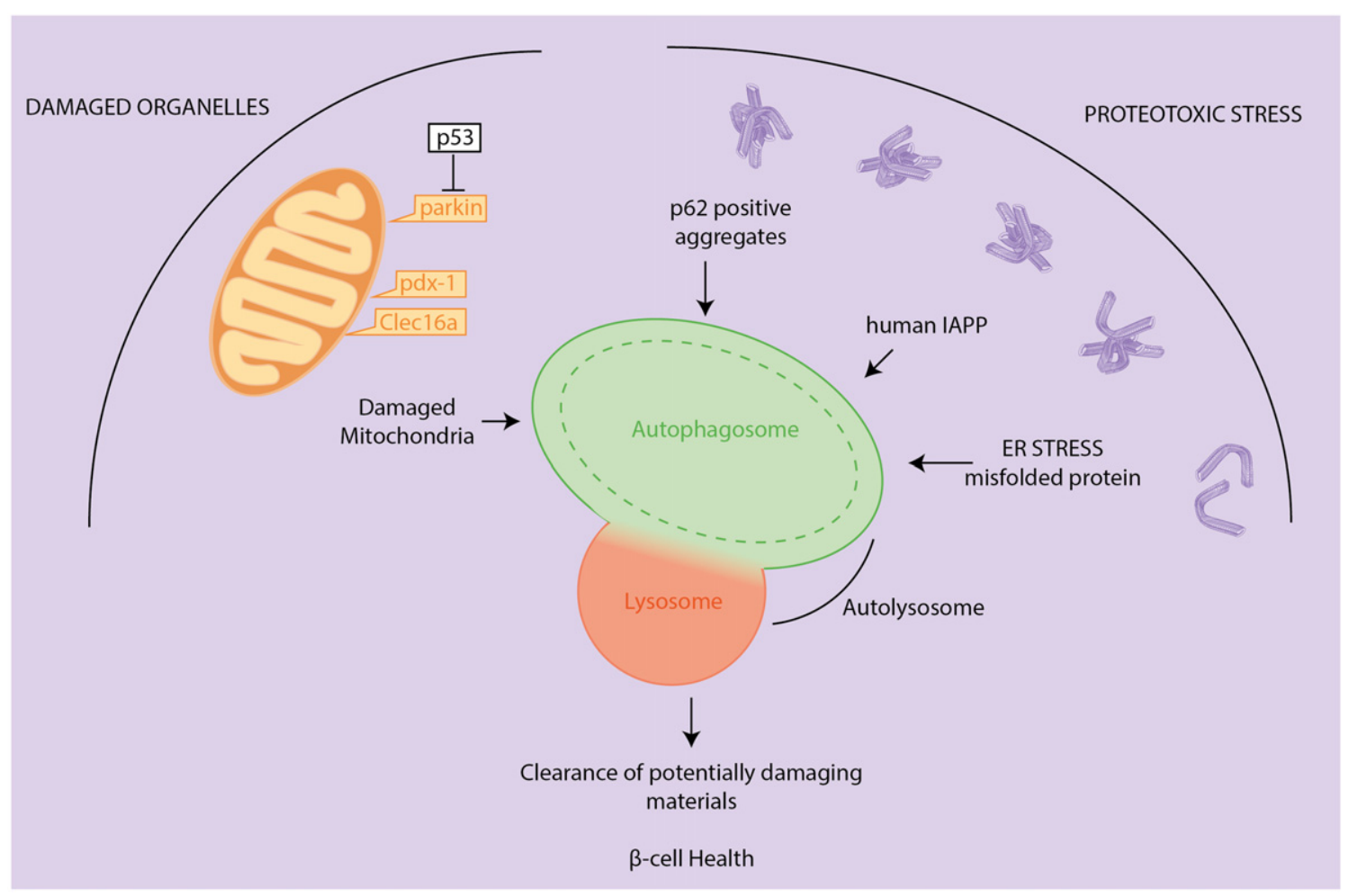

Fig. 2. Multifaceted role of macroautophagy in protection against $\beta$-cell failure. Macroautophagy is involved in the clearance of damaged organelles including mitochondria (mitophagy) and promotes degradation of misfolded proteins and protein aggregates - heavy burdens of specialized secretory machines as found in the $\beta$ cell. 
Clec16a led to the accumulation of damaged mitochondria, decreased insulin secretion, glucose intolerance and hyperglycemia [46]. In line with these findings, downregulation of the key mitophagy regulator Parkin compromised insulin secretion in $\beta$ cell models [47]. Interestingly, activity of Parkin has been shown to be directly inhibited by tumor suppressor p53 in a streptozotocin-induced diabetes model as well as in leptin receptor-deficient $d b / d b$ mice, thus identifying p53 as a key regulator of mitophagy in $\beta$ cells [48].

The protective role of macroautophagy in $\beta$ cells has been also demonstrated in Akita mice, a model of diabetes, in which a mutation in proinsulin leads to its severe misfolding provoking ER stress [49]. A small (37 amino acids) human islet amyloid polypeptide (IAPP) is normally co-secreted with insulin inside secretory granules, but is also prone to form oligomers and extracellular amyloid plaques frequently observed in islets of T2D patients [50]. Several lines of evidence corroborate macroautophagy as a protective pathway against the cytotoxic effects of human IAPP (at least in mice models expressing human IAPP): first, the enhanced expression of human IAPP activated macroautophagy; second, the clearance of IAPP oligomers occured via macroautophagy; and third, blocking macroautophagy (using $A \operatorname{tg} 7^{\beta c e l l} \mathrm{KO}$ ) in human IAPPexpressing mice led to diabetes [51-54]. In addition, forced expression of human IAPP in $\beta$ cells of female pregnant mice recapitulated the features of pregnancy-related diabetes, and was characterized by compromised macroautophagy [55].

\section{Compromised macroautophagy in $\beta$ cells in diabetes}

Altered levels of macroautophagy have been reported in isolated islets and cellular models where the diabetic environment was mimicked to a certain degree by adding high amounts of glucose and/or free fatty acids such as palmitate (gluco - and lipotoxicity models). In particular, shorter exposure of $\beta$ cells increased macroautophagy, while prolonged treatment led to decreased macroautophagy (resembling what has been observed in T2D patients, see below) [56-63]. For example, a $\beta$ cell model, rat insulinoma-derived INS-1E cells, demonstrated a time-dependent increase in LC3-II upon palmitate (up to $8 \mathrm{~h}$ ), followed by a decrease in LC3-II, while isolated human islets increased LC3-II signals up to $48 \mathrm{~h}$ of treatment [58]. Similarly, INS-1E cells showed a time-dependent increase in autophagic flux upon palmitate treatment (up to 8-16 h), followed by a decrease (at $24 \mathrm{~h}$ ) as compared to controltreated cells [62]. In mice, high fat diet led to an increase in the number of autophagosomes in $\beta$ cells as well as to an increased autophagic flux, indicating increased macroautophagy $[42,64]$. One recently proposed mechanism for the compensatory stimulation of macroautophagy involves complement C3, a component of the complement system, which is highly expressed in human pancreatic islets and has been shown to promote macroautophagy via its interaction with macroautophagy protein ATG16L1 [65]. However, increased p62 levels indicative of compromised macroautophagy were observed in $\beta$ cells of $o b / o b$ mice as well as $d b / d b$ mice thus suggesting that macroautophagy eventually fails to cope with metabolic challenges in models of severe obesity $[43,66]$.

An increased fraction of $\beta$ cells with massive vacuole overload and increased volume density of autophagic structures in $\beta$ cells were initially reported in T2D patients [67]. Mechanistically, more recent studies revealed elevated levels of the macroautophagy substrate p62 [68-70] and decreased levels of the autophagosomes marker LC3-II [70] in $\beta$ cells of T2D patients, consistent with decreased macroautophagy in $\beta$ cells in T2D.

Taken together, accumulating evidence supports a protective role of macroautophagy with compromised $\beta$ cell macroautophagy being one of the components of diabetes.

\section{Stimulating $\beta$ cell macroautophagy: potential therapies in diabetes?}

In light of above findings, it is not surprising that reactivation or upregulation of macroautophagy in $\beta$ cells has recently become a rapidly emerging research area in the diabetes field.

The major metabolic regulator mTORC1 that, among other effects, suppresses macroautophagy at multiple levels including autophagosome biogenesis [71-76], is considered to be one of the contributing factors to macroautophagy dysfunction in the diabetic $\beta$ cell. Accordingly, geneticallyinduced mTORC 1 hyperactivity promoted onset of diabetes in mice due to compromised macroautophagy [77]. Indeed, in Akita mice, stimulation of $\beta$ cell macroautophagy by rapamycin-mediated inhibition of mTOR prevented $\beta$ cell apoptosis, increased pancreatic insulin content and ameliorated diabetes [78]. Furthermore, rapamycin-mediated stimulation of macroautophagy restored insulin secretion in palmitate-treated INS1 cells, decreased apoptosis in palmitate-treated INS1 and MIN6 cells as well as human islets [56,59], and increased insulin secretion and decreased apoptosis in palmitate-treated nondiabetic human islets and in human islets isolated from T2D patients [79]. The importance of mTORC1mediated suppression of macroautophagy in the $\beta$ cell is further reflected by the fact that the recently discovered mTORC1-independent macroautophagy inducer MSL-7 had virtually no effect in the $\beta$ cell of high fat diet-fed mice, while being a potent activator of macroautophagy in liver and adipose tissue [80]. 
However, long-term or chronic inactivation of mTOR are deleterious due to pleiotropic effects of mTOR signaling, thus emphasizing the need for more tailored mTOR-targeting strategies in the context of $\beta$ cell failure [81-84].

Disaccharide trehalose has been described as a potent inducer of macroautophagy in different models $[85,86]$. In the context of the $\beta$ cell, trehalose treatment has been reported to accelerate clearance of human IAPP oligomers in human IAPP. expressing mice [54]. However, it should be noted that the role of trehalose in the regulation of macroautophagy might be more complex than initially proposed [87].

Interestingly, several well-known anti-diabetic drugs have been reported to increase $\beta$ cell macroautophagy in different models of diabetes. In addition, a number of potential therapies targeting specifically macroautophagy and/or lysosomal function have recently emerged. The most commonly prescribed drug for T2D, metformin, has been reported to improve macroautophagy in $\beta$ cells via AMP-activated protein kinase (AMPK) [88]. Multiple research efforts provided evidence that stimulation of macroautophagy in the $\beta$ cell might contribute to the beneficial effects of Glucagon-like peptide-1 (Glp-1), Glp-1 receptor agonists and Dipeptidyl peptidase-4 (DPP4) inhibitors in addition to their role in regulation of insulin secretion. In particular, the Glp-1 receptor agonists, liraglutide and exendin-4 have been shown to promote macroautophagy in INS1 cells, isolated human islets and in rodent diabetes models [85-87] [89-91], and DPP4 inhibitor MK-626 increased macroautophagy in the islets isolated from high fat diet-fed mice [92]. The molecular mechanisms, underlying these effects as well as the exact role of macroautophagy in the therapeutic effects of Glp1 mimetics needs to be further explored. In fact, another report observed that Exendin-4 was efficient in improving the $\beta$ cell function in macroautophagy-deficient $\beta$ cells and in $A \operatorname{tg} 7^{\text {Bcell }}$ KO mice mainly through augmented insulin secretion and decreased $\beta$ cell apoptosis [66].

In addition to therapeutic agents discussed above, calorie restriction or intermittent fasting have been proposed to reverse diabetes [93,94]. Interestingly, Liu et al. have observed that intermittent fasting restored macroautophagy (autophagic flux), improved glucose tolerance and glucose stimulated insulin secretion, as well as $\beta$ cell survival [95]. Interestingly, intermittent fasting did not improve $\beta$ cell survival or regeneration in lysosomal associated membrane protein-2 (Lamp2) knockout mice, again suggesting a central role of lysosome function in $\beta$ cell homeostasis. In line with this notion, recent studies have proposed to improve lysosomal function in the $\beta$ cell by using bioengineered nanoparticles designed to lower lysosomal pH $[96,97]$.
Collectively, these promising studies indicate a high therapeutic potential for macroautophagy stimulation to protect the $\beta$ cell. Yet, a more controlled and targeted manner of enhancing macroautophagy needs to be achieved. We believe that a better understanding of mechanisms leading to compromised macroautophagy in $\beta$ cells in diabetes will help to address these problems.

\section{Crinophagy: An active role in $\beta$ cell function and T2D?}

The predominant function of the pancreatic $\beta$ cell is to release insulin in response to nutrients. Insulin synthesis starts with the precursor preproinsulin, which is subjected to cotranslational translocation into the RER lumen and $\mathrm{N}$-terminal signal peptide cleavage. The resulting luminal proinsulin in turn is properly folded and probably subjected to initial packaging and sorting as reported for other cargo proteins in the RER [98]. Proinsulin is then transported to the TGN, where major packaging and sorting events occur resulting in the formation of immature secretory granules. Immature secretory granules are acidified through the action of the ATPdependent proton pump, which results in cleavage of proinsulin into insulin and C-peptide. Cleavage is followed by insulin crystallization with zinc and calcium converting immature secretory granules into mature dense-core granules. Insulin in turn is released from dense-core granules upon their fusion with the plasma membrane [99]. Dense-core granules are found in two major populations, the readily releasable pool (RRP) and the reserve pool. Being in close association with the plasma membrane, the RRP is primed to immediately release insulin in response to an appropriate stimulation. The reserve pool comprises granules that are more distant of the plasma membrane requiring trafficking prior fusion. The two pools may account for the immediate/short first and delayed/prolonged second phase of insulin secretion, respectively [100].

Even if insulin granules are properly formed, not all insulin is secreted, some is degraded via crinophagy, which in the $\beta$ cell was first described by Lelio Orci $[101,102]$. Crinophagy is a pathway different from macroautophagy, as it does not rely on autophagosomes, but instead represents direct fusion of granules with lysosomes. The mechanistic distinctions between crinophagy and macroautophagy were further highlighted in a recent study that demonstrated that induction of developmentally programmed crinophagy in drosophila did not require canonical mediators of macroautophagy [15]. Crinophagy has initially been observed in $\beta$ cells of different animal models [103-105], of diabetic rodents [104] and also of islets upon inhibition of secretion [106-113]. As in other secretory cells, crinophagy thus constitutes a frequent 
phenomenon in islet $\beta$ cells. In fact, its capacity to remove insulin must be considerable provided that most synthesized proinsulin escapes endoplasmic reticulum-associated protein degradation (ERAD) and is incorporated into secretory vesicles. Quantitative analysis in murine islets revealed that a $\beta$ cell contains approximately $13^{\prime} 000$ insulin granules on average [114], while the number of lysosomes per cell ranges between 25 and 70 [115]. Given the fact that at least $30 \%$ of insulin in islets can be degraded within $24 \mathrm{~h}$ $[102,116]$, each lysosome is supposed to fuse with several secretory granules in line with the appearance of multigranular bodies.

Based on the initial correlative studies, it was concluded that crinophagy acts to prevent accumulation of insulin granules in a situation where insulin secretion is compromised. In a way, crinophagy in the $\beta$ cell was regarded as a passive consequence of lower secretion and thus appeared to be devoid of any major regulation.

This view has been recently challenged by our own work. Our initial observation was that $\beta$ cells upon short-term nutrient deprivation in vitro and in vivo suppressed macroautophagy, very much in contrast to other mammalian cells that induced macroautophagy in response to the same challenge. In fact, lysosomal degradation of autophagosomederived cellular material is a main catabolic response providing nutrients if not available in the environment. This prompted us to seek for alternative nutrient sources in starved/fasted $\beta$ cells. We found that the predominant initial response in $\beta$ cells was to directly fuse insulin granules with the lysosome under these conditions, highly reminiscent of crinophagy and independent of macroautophagy.

Interestingly, we found that nascent insulin granules containing proinsulin close to the Golgi were predominantly targeted to lysosomal degradation under these conditions. We termed the observed process starvation-induced nascent granule degradation (SINGD, pronounced ['sIndi]) [117], proposing that crinophagic mechanisms may underlie SINGD. Strikingly, we also found that mTOR was recruited to SINGD compartments leading to local mTOR activation and mTOR-mediated inhibitory phosphorylation of Unc-51 like autophagy activating kinase 1 (ULK1), a kinase that promotes early steps of autophagophore formation [118]. Activation of mTOR in distinct compartments has been shown to result in specific downstream responses [119]. This is in line with our observation that mTOR activation in the SINGD compartment is sufficient to suppress macroautophagy but not to induce protein translation. Thus, induction of SINGD was directly linked to the observed suppression of macroautophagy.

Another basic observation prompted us to speculate about a specific function of SINGD. We found that forcing macroautophagy in isolated human and murine islets using short term treatment with macroautophagy-inducing peptide, Tat-Beclin1 [120] under basal non-stimulatory glucose levels de-repressed insulin secretion almost to stimulatory levels arguing that macroautophagy may stimulate insulin release. In other words, SINGD-mediated suppression of macroautophagy might be necessary to prevent insulin release under fasting conditions. In fact, degradation in autolysosomes may generate metabolites that trigger insulin release. The spectrum of metabolites that have been demonstrated to have the capacity to stimulate insulin secretion is indeed very broad [121]. Future studies, including specific inhibition of macroautophagy, will be necessary to confirm this specific function of SINGD. In addition to suppression of macroautophagy, we have proposed that SINGD removes secretory granules omitting release of insulin under low nutrient conditions. Indeed, newly synthesized insulin was shown to be preferentially released upon nutrient stimulation [122]. Importantly, SINGDmediated suppression of macroautophagy depends on abundant nascent SGs. Therefore the depletion of nascent SGs (for example, in the course of SINGD upon prolonged fasting) is likely to de-repress macroautophagy without the danger of increasing insulin release.

As mentioned above, crinophagy is likely to be the main route for SINGD; however, it is important to emphasize again that substrates of crinophagy are not restricted to nascent insulin granules. Instead, crinophagy has been implicated in the disposal of old granules and in the compensatory degradation of granules that accumulate upon secretory defects [123]. Thus, unraveling the molecular mechanisms underlying SINGD (see below) is necessary to establish the exact relations between SINGD and crinophagy. In addition, given the recent discovery of molecular mechanisms of crinophagy in Drosophila [15], it will be important to test their relevance in the $\beta$ cell, and in particular in SINGD. Taken together, SINGD might represent a specific form of crinophagy in the context of low nutrient availability in the $\beta$ cell, arguing for an evolutionary driven adaptation in a cell type in which nutrient sensing is directly coupled to secretion.

Does macroautophagy participate in the degradation of secretory granules? It seems a possible scenario that insulin granules in principle reach lysosomes via autophagosomes along with other cytosolic material. To date, evidence supports this possibility in model systems in which components of macroautophagy and/or of the secretory pathway have been altered. In particular, incidents of autophagosomes containing secretory granules (along with crinophagy, microautophagy and increased amounts of multigranular bodies) were reported in secretory-deficient Rab3A knockout mice using electron microscopy [123]. In addition, increased levels of autophagosomes containing secretory 
granules have been observed in cellular models over-expressing the components of macroautophagy [124] and in high-fat diet-fed knockin mice bearing a constitutive active mutation of Becn1 (beclin1) - Becn1 ${ }^{\mathrm{F} 121 \mathrm{~A}}$ [125]. Expression of Becn1F121A promoted loss of insulin in high fat-fed mice, which correlated with increased accumulation of insulin inside autophagosomes/autolysosomes. In striking contrast, mice expressing wild-type alleles of Becn1 demonstrated very low levels of insulin detected within LC3-GFP autophagic structures [125]. In addition, Riahi et al. described that treatment of $\beta$ cells with bafilomycin A1 (BafA1) led to markedly increased co-localization between insulin granules and lysosomes [124]. Among other effects, BafA1 blocks fusion of autophagosomes with lysosomes [126,127], which prevents autophagosomal delivery of insulin granules to lysosomes. Delivery of insulin granules to lysosomes through macroautophagy is thus excluded under these conditions, contradicting a model in which macroautophagy represents a major pathway for lysosomal insulin granule degradation. Furthermore, studies of $A t g 7^{\text {Bcell KO }}$ mice observed marked loss of insulin and insulin granules in $\beta$ cells in islets of macroautophagy-deficient mice as compared to $\beta$ cells in islets of control mice [41]. The loss of insulin in macroautophagy-deficient conditions seems counter-intuitive, if macroautophagy were to be the main mechanism of insulin granule delivery to lysosomes. Taken together, it thus remains to be experimentally tested to which extent macroautophagy participates in secretory granule disposal under normal conditions.

More recently, the group of Shigeomi Shimizu, which had previously discovered ATG5/ATG7 independent alternative macroautophagy [128], has demonstrated that $\beta$ cells, in which canonical macroautophagy was ablated, engage Golgimediated formation of phagophore-like structures that engulf insulin granules resulting in granule containing autophagosome-like structures that finally fuse with lysosomes [129]. They termed this process Golgi membrane-associated degradation (GOMED). Mechanistically, GOMED is certainly distinct from canonical macroautophagy but also from crinophagy, and our morphologic analyses did not show evidence for GOMED in macroautophagy-proficient $\beta$ cells subjected to nutrient deprivation. However, it is very intriguing that two macroautophagy-independent Golgi-related lysosomal pathways, SINGD in macroautophagyproficient $\beta$ cells and GOMED in macroautophagydeficient $\beta$ cells control the disposal of secretory granules. We believe that future studies will shed light on whether GOMED is relevant in $\beta$ cells in which the canonical macroautophagy machinery is intact, and address potential interactions between SINGD and GOMED.
Another very important question is as to how SINGD is regulated at the molecular level. Our data clearly favor a crinophagic process to underlie SINGD and hence two more precise questions arise: What are the signals determining whether an insulin granule is routed to the lysosome for degradation or to the plasma membrane for secretion and where are these signals emerging from? As outlined above, insulin granule biogenesis occurs at the TGN. It is thus tempting to speculate that this regulation occurs in this compartment. One of the major regulators of transport carrier formation at the TGN is protein kinase D (PKD) [130]. Our laboratory has initially demonstrated the requirement of PKD in insulin granule formation $[131,132]$. Strikingly, PKD inhibition or knockdown leads to constitutive induction of SINGD and mTOR-mediated suppression of macroautophagy no matter whether cells have been deprived from nutrients or not [117]. Therefore, insulin granules most likely receive initial signals that determine their fate already at the TGN. Several substrates of PKD at the TGN have already been identified. Among them, oxysterol-binding protein (OSBP) could be particularly interesting in the context of SINGD. In fact, a recent study demonstrated that the knockdown of OSBP in $\beta$ cells causes crinophagic delivery of nascent insulin granules to lysosomes independent of macroautophagy referring to SINGD [133]. Another interesting target of PKD is phosphoinositol 4 kinase $3 \beta$ (PI4KIII $\beta$ ) [134]. PI4KIII $\beta$ together with PI4KIIa mainly control $\mathrm{PI}(4) \mathrm{P}$ levels in Golgi membranes [135]. PI(4)P is an essential lipid at the crossroad of Golgi function [136]. Our laboratory also identified Arfaptin-1 as a PKD target and demonstrated that timely phosphorylation of Arfaptin-1 is essential for insulin granule detachment from the TGN to occur. Moreover, Arfaptin-1-depleted $\beta$ cells showed markedly enhanced proinsulin degradation [132]. Importantly, both OSBP and Arfaptin-1 bind to $\mathrm{PI}(4) \mathrm{P}[136,137]$. Interestingly, GOMED in macroautophagy-deficient yeast cells could also be induced through depletion of PI(4)P [129]. Together, this suggests that PKD-mediated control of PI4Pdependent effector functions at the TGN prevents SINGD and favors routing of insulin granules for secretion (Fig. 3). The fact that short-term nutrient depletion can actively engage SINGD to avoid macroautophagy-induced insulin secretion suggests the presence of yet to be identified pathways that directly link nutrient sensing to Golgi function.

Another interesting protein in the context of SINGD might be BAIAP3, a C2 domain-containing Munc13 protein. BAIAP3 is involved in retrograde trafficking from endosomes to the TGN, which was enhanced upon $\mathrm{Ca}^{2+}$-triggered exocytosis. Importantly, BAIAP3 depletion in $\beta$ cells provoked crinophagic delivery of immature insulin granules to lysosomes and their degradation [138]. This work may suggest 


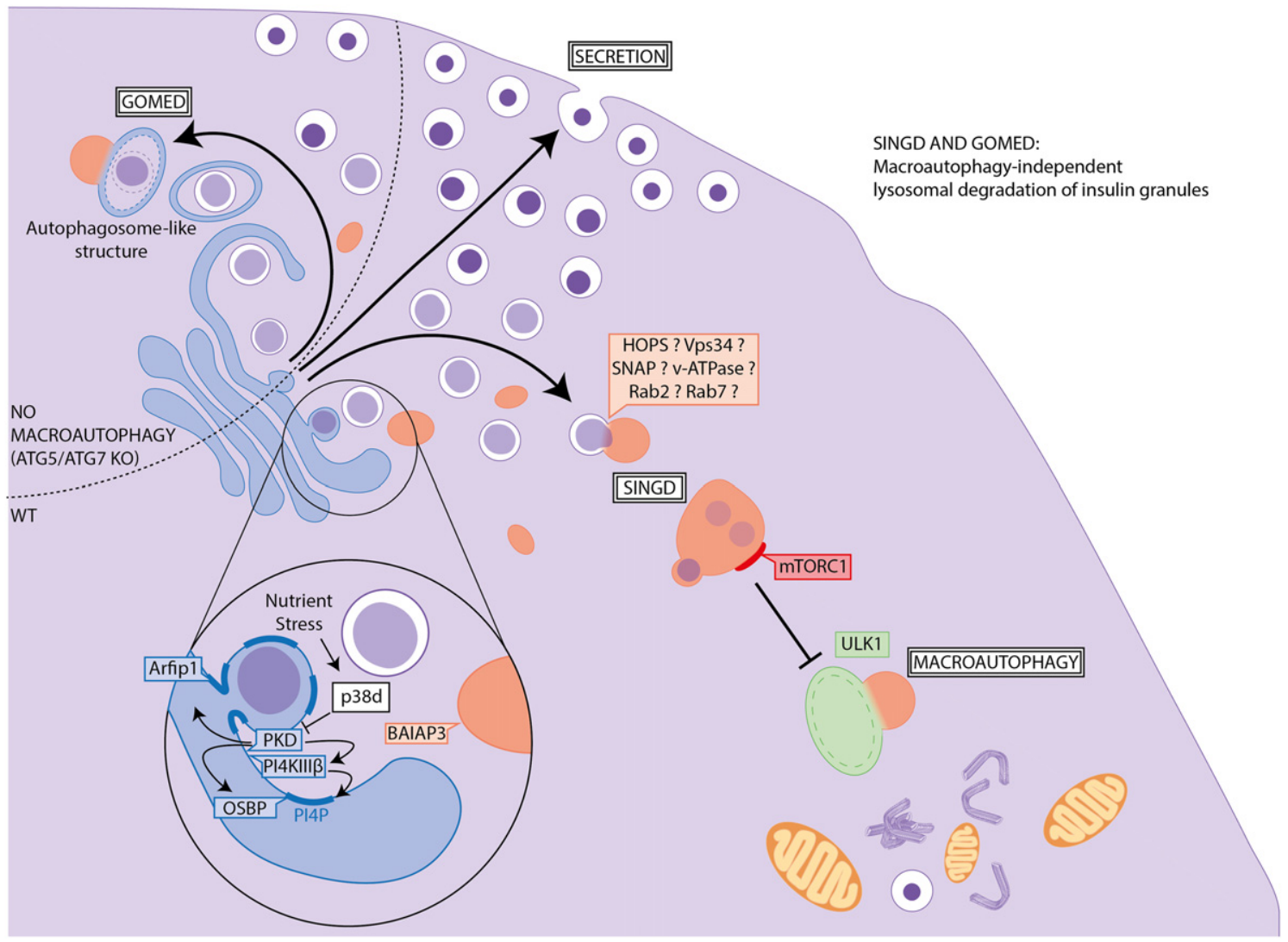

Fig. 3. Macroautophagy-independent lysosomal degradation of insulin granules is linked with Golgi function. SINGD in macroautophagy-competent cells and GOMED in macroautophagy-deficient cells control the fate of secretory granules. SINGD pathway promotes crinophagic lysosomal degradation of nascent granules, leading to lysosomal recruitment and activation of mTORC1, which suppresses macroautophagy.

that $\mathrm{Ca}^{2+}$-driven efficient recycling of proteins from endosomes is yet another important process preventing SINGD (Fig. 3). In addition, mechanisms necessary to fuse nascent insulin granules with lysosomes might be similar to the ones previously described for developmentally programmed crinophagy in drosophila [15] (Fig. 3).

We have also demonstrated that the stressactivated kinase p38 $\delta$ phosphorylates and inhibits PKD activity in $\beta$ cells [131]. Importantly, inactivation of $\mathrm{p} 38 \delta$ and as a consequence activation of PKD counteracts SINGD and promotes macroautophagy as well as insulin release $[117,131]$.

While p38ס activation might be adaptive in response to short-term stress for example upon nutrient deprivation, chronically enhanced p38ס activity may interfere with $\beta$ cell function. A prevailing concept in T2D is that activation of stress kinases in multiple organs contributes to disease progression. Stress kinase signaling has been shown to directly interfere with insulin signaling and thus constitutes an important mechanism of insulin resistance [139]. It is also established that such stress mechanisms may contribute to $\beta$ cell failure in T2D. Inflammatory, oxidative and ER stress were reported as main mechanisms promoting $\beta$ cell dysfunction in T2D [140-142]. We have shown that $p 38 \delta$ deletion in mice alleviated oxidative-stress induced $\beta$ cell loss in a PKD-dependent manner [131]. Given the role of PKD in prevention of SINGD, it is tempting to speculate that stress-induced p38ס activation may trigger SINGD-dependent insulin granule loss and suppression of macroautophagy, important hallmarks of $\beta$ cell decompensation. It will thus be important to address whether changes in this regulatory system actively contributes to T2D.

\section{Chaperone-mediated Autophagy and Microautophagy in the $\beta$ cell}

Chaperone-mediated Autophagy (CMA), as well as microautophagy, have been poorly explored in the $\beta$ cell. Interestingly, CMA was linked to glucose metabolism through glycolytic enzymes, such as Glyceraldehyde 3-phosphate dehydrogenase (GAPDH) and Aldolase, which were first identified as CMA substrates in the liver [143]. However, to 
date, this link was established only in liver, using liver-specific conditional knockout mouse for Lamp-2a, the limiting component in CMA (Alb-CRE:Lamp-2a-/-) [144]. In particular, Alb-CRE: Lamp-2a-/- exhibited a hepatic glycogen depletion accompanied by reduced peripheral adiposity, increased energy expenditure, and enhanced glucose tolerance. As glucose metabolism is a central part of the regulation of insulin secretion, it will be interesting to test the potential relevance of CMA in the $\beta$ cell.

As specific mechanisms underlying microautophagy remain largely unknown, it is challenging to study its role in a given biological context. Marsh et al. reported enhanced microautophagy in $\beta$ cells of RAB3A knockout mice [123] but its role in $\beta$ cell function remains to be unveiled.

\section{Conclusion}

Different pathways ultimately feeding lysosomes with cellular material for degradation were demonstrated to have an impact on pancreatic $\beta$ cell function. In the last years, major emphasis has been placed on the study of macroautophagy in this context. Enhancing macroautophagy is important to maintain the fidelity of the secretory apparatus in conditions of high insulin demands. Failures in these adaptive mechanisms are likely to contribute to $\beta$ cell failure. In comparison, macroautophagyindependent processes targeting cellular material to lysosomes and lysosomal function were less investigated in the $\beta$ cell field. Recent reports suggest that crinophagy/SINGD and its inhibitory role on macroautophagy constitutes another important mechanism controlling $\beta$ cell function. The exact mechanism of crinophagy/SINGD as well as its role in diabetes requires further investigation in the near future. The role of microautophagy as well as CMAmediated autophagy remains to be explored in the $\beta$ cell. Identification of the molecular mechanisms controlling these processes may open new opportunities for drug development in the context of T2D.

\section{Acknowledgements}

This review was supported by the Agence Nationale de la Recherche (ANR) (AAPG 2017 LYSODIABETES), by the European Foundation for the Study of Diabetes (EFSD)/Lilly European Diabetes Research Programme grant as well as an EFSD/ Novo Nordisk grant, by a European Research Council (ERC) starting grant (ERC-2011-StG, 281271-STRESS METABOL) and by the ANR-10LABX-0030-INRT grant, a French State fund managed by the ANR under the frame program
Investissements d'Avenir ANR-10-IDEX-0002-02. A. Pasquier was supported by a FRM fellowship (fin de thèse). A. Goginashvili was supported by the ERC grant and the EFSD/Lilly European Diabetes Research Programme grant. K. Vivot was supported by a FRM fellowship ARF20160936008 and an Individual Fellowship (798961 INSULYSOSOME) in the framework of the Marie-Sklodovska Curie actions of the European Commission.

Received 27 June 2019; Received in revised form 19 July 2019; Accepted 19 July 2019 Available online 02 August 2019

Keywords: Diabetes; Lysosome; Autophagy; Crinophagy; Nutrient signaling

These authors contributed equally to this review article.

\section{References}

[1] F. Appelmans, R. Wattiaux, C. De Duve, Tissue fractionation studies. 5. The association of acid phosphatase with a special class of cytoplasmic granules in rat liver, Biochem. J. 59 (1955) 438-445, https://doi.org/10.1042/bj0590438.

[2] D.D. Sabatini, M. Adesnik, Christian de Duve: explorer of the cell who discovered new organelles by using a centrifuge, Proc. Natl. Acad. Sci. U. S. A. 110 (2013) 13234-13235, https://doi.org/10.1073/pnas.1312084110.

[3] D.F. Bainton, The discovery of lysosomes, J. Cell Biol. 91 (1981) 66-76, https://doi.org/10.1083/jcb.91.3.66s.

[4] A.B. Novikoff, H. Beaufay, C. De Duve, Electron microscopy of lysosomerich fractions from rat liver, J. Biophys. Biochem. Cytol. 2 (1956) 179-184.

[5] M.G. Farquhar, D.F. Bainton, M. Baggiolini, C. de Duve, Cytochemical localization of acid phosphatase activity in granule fractions from rabbit polymorphonuclear leukocytes, J. Cell Biol. 54 (1972) 141-156.

[6] E.J. Blott, G.M. Griffiths, Secretory lysosomes, Nat. Rev. Mol. Cell Biol. 3 (2002) 122-131, https://doi.org/10.1038/nrm732.

[7] P. Saftig, J. Klumperman, Lysosome biogenesis and lysosomal membrane proteins: trafficking meets function, Nat. Rev. Mol. Cell Biol. 10 (2009) 623-635, https://doi.org/ 10.1038/nrm2745.

[8] S. Mayor, R.E. Pagano, Pathways of clathrin-independent endocytosis, Nat. Rev. Mol. Cell Biol. 8 (2007) 603-612, https://doi.org/10.1038/nrm2216.

[9] M. Kaksonen, A. Roux, Mechanisms of clathrin-mediated endocytosis, Nat. Rev. Mol. Cell Biol. 19 (2018) 313-326, https://doi.org/10.1038/nrm.2017.132.

[10] C.A. Lamb, T. Yoshimori, S.A. Tooze, The autophagosome: origins unknown, biogenesis complex, Nat. Rev. Mol. Cell Biol. 14 (2013) 759-774, https://doi.org/10.1038/nrm3696. 
[11] A.L. Anding, E.H. Baehrecke, Autophagy in cell life and cell death, Curr. Top. Dev. Biol. 114 (2015) 67-91, https://doi. org/10.1016/bs.ctdb.2015.07.012.

[12] W. Li, J. Li, J. Bao, Microautophagy: lesser-known selfeating, Cell. Mol. Life Sci. CMLS. 69 (2012) 1125-1136, https://doi.org/10.1007/s00018-011-0865-5.

[13] S. Kaushik, A.M. Cuervo, Chaperone-mediated autophagy: a unique way to enter the lysosome world, Trends Cell Biol. 22 (2012) 407-417, https://doi.org/10.1016/j.tcb.2012.05.006.

[14] R.E. Smith, M.G. Farquhar, Lysosome function in the regulation of the secretory process in cells of the anterior pituitary gland, J. Cell Biol. 31 (1966) 319-347.

[15] T. Csizmadia, P. Lőrincz, K. Hegedűs, S. Széplaki, P. Lőw, G. Juhász, Molecular mechanisms of developmentally programmed crinophagy inDrosophila, J. Cell Biol. 217 (2018) 361-374, https://doi.org/10.1083/jcb.201702145.

[16] J. Heitman, N.R. Movva, M.N. Hall, Targets for cell cycle arrest by the immunosuppressant rapamycin in yeast, Science. 253 (1991) 905-909.

[17] R. Loewith, E. Jacinto, S. Wullschleger, A. Lorberg, J.L. Crespo, D. Bonenfant, W. Oppliger, P. Jenoe, M.N. Hall, Two TOR complexes, only one of which is rapamycin sensitive, have distinct roles in cell growth control, Mol. Cell 10 (2002) 457-468.

[18] Y. Sancak, L. Bar-Peled, R. Zoncu, A.L. Markhard, S. Nada, D.M. Sabatini, Ragulator-rag complex targets mTORC1 to the lysosomal surface and is necessary for its activation by amino acids, Cell. 141 (2010) 290-303, https://doi.org/10. 1016/j.cell.2010.02.024

[19] L. Yu, C.K. McPhee, L.X. Zheng, G.A. Mardones, Y.G. Rong, J.Y. Peng, N. Mi, Y. Zhao, Z.H. Liu, F.Y. Wan, D.W. Hailey, V. Oorschot, J. Klumperman, E.H. Baehrecke, M.J. Lenardo, Termination of autophagy and reformation of lysosomes regulated by mTOR, Nature. 465 (2010) 942-U11, https://doi.org/10.1038/Nature09076.

[20] G. Napolitano, A. Esposito, H. Choi, M. Matarese, V. Benedetti, C. Di Malta, J. Monfregola, D.L. Medina, J. Lippincott-Schwartz, A. Ballabio, mTOR-dependent phosphorylation controls TFEB nuclear export, Nat. Commun. 9 (2018) 3312, https://doi.org/10.1038/s41467-018-05862-6.

[21] R.L. Wolfson, D.M. Sabatini, The Dawn of the age of amino acid sensors for the mTORC1 pathway, Cell Metab. 26 (2017) 301-309, https://doi.org/10.1016/j.cmet.2017.07.001.

[22] C.-S. Zhang, B. Jiang, M. Li, M. Zhu, Y. Peng, Y.-L. Zhang, Y.-Q. Wu, T.Y. Li, Y. Liang, Z. Lu, G. Lian, Q. Liu, H. Guo, Z. Yin, Z. Ye, J. Han, J.-W. Wu, H. Yin, S.-Y. Lin, S.-C. Lin, The lysosomal v-ATPase-Ragulator complex is a common activator for AMPK and mTORC1, acting as a switch between catabolism and anabolism, Cell Metab. 20 (2014) 526-540, https://doi.org/10.1016/j.cmet.2014.06.014.

[23] D.J. Klionsky, K. Abdelmohsen, A. Abe, M.J. Abedin, H. Abeliovich, A. Acevedo Arozena, H. Adachi, C.M. Adams, P.D. Adams, K. Adeli, P.J. Adhihetty, S.G. Adler, G. Agam, R. Agarwal, M.K. Aghi, M. Agnello, P. Agostinis, P.V. Aguilar, J. Aguirre-Ghiso, E.M. Airoldi, S. Ait-Si-Ali, T. Akematsu, E.T. Akporiaye, M. Al-Rubeai, G.M. Albaiceta, C. Albanese, D. Albani, M.L. Albert, J. Aldudo, H. Algül, M. Alirezaei, I. Alloza, A. Almasan, M. Almonte-Beceril, E.S. Alnemri, C. Alonso, N. Altan-Bonnet, D.C. Altieri, S. Alvarez, L. Alvarez-Erviti, S. Alves, G. Amadoro, A. Amano, C. Amantini, S. Ambrosio, I. Amelio, A.O. Amer, M. Amessou, A. Amon, Z. An, F.A. Anania, S.U. Andersen, U.P. Andley, C.K. Andreadi, N. Andrieu-Abadie, A. Anel, D.K. Ann, S. Anoopkumar-Dukie, M. Antonioli, H. Aoki, N. Apostolova, S.
Aquila, K. Aquilano, K. Araki, E. Arama, A. Aranda, J. Araya, A. Arcaro, E. Arias, H. Arimoto, A.R. Ariosa, J.L. Armstrong, T. Arnould, I. Arsov, K. Asanuma, V. Askanas, E. Asselin, R. Atarashi, S.S. Atherton, J.D. Atkin, L.D. Attardi, P. Auberger, G. Auburger, L. Aurelian, R. Autelli, L. Avagliano, M.L. Avantaggiati, L. Avrahami, S. Awale, N. Azad, T. Bachetti, J.M. Backer, D.-H. Bae, J.-S. Bae, O.-N. Bae, S.H. Bae, E.H. Baehrecke, S.-H. Baek, S. Baghdiguian, A. Bagniewska-Zadworna, H. Bai, J. Bai, X.-Y. Bai, Y. Bailly, K. N. Balaji, W. Balduini, A. Ballabio, R. Balzan, R. Banerjee, G. Bánhegyi, H. Bao, B. Barbeau, M.D. Barrachina, E. Barreiro, B. Bartel, A. Bartolomé, D.C. Bassham, M.T. Bassi, R.C. Bast, A. Basu, M.T. Batista, H. Batoko, M. Battino, K. Bauckman, B.L. Baumgarner, K.U. Bayer, R. Beale, J.-F. Beaulieu, G.R. Beck, C. Becker, J.D. Beckham, P.-A. Bédard, P.J. Bednarski, T.J. Begley, C. Behl, C. Behrends, G.M. Behrens, K.E. Behrns, E. Bejarano, A. Belaid, F. Belleudi, G. Bénard, G. Berchem, D. Bergamaschi, M. Bergami, B. Berkhout, L. Berliocchi, A. Bernard, M. Bernard, F. Bernassola, A. Bertolotti, A.S. Bess, S. Besteiro, S. Bettuzzi, S. Bhalla, S. Bhattacharyya, S.K. Bhutia, C. Biagosch, M.W. Bianchi, M. Biard-Piechaczyk, V. Billes, C. Bincoletto, B. Bingol, S.W. Bird, M. Bitoun, I. Bjedov, C. Blackstone, L. Blanc, G.A. Blanco, H.K. Blomhoff, E. Boada-Romero, S. Böckler, M. Boes, K. BoeszeBattaglia, L.H. Boise, A. Bolino, A. Boman, P. Bonaldo, M. Bordi, J. Bosch, L.M. Botana, J. Botti, G. Bou, M. Bouché, M. Bouchecareilh, M.-J. Boucher, M.E. Boulton, S.G. Bouret, P. Boya, M. Boyer-Guittaut, P.V. Bozhkov, N. Brady, V.M. Braga, C. Brancolini, G.H. Braus, J.M. BravoSan Pedro, L.A. Brennan, E.H. Bresnick, P. Brest, D. Bridges, M.-A. Bringer, M. Brini, G.C. Brito, B. Brodin, P.S. Brookes, E.J. Brown, K. Brown, H.E. Broxmeyer, A. Bruhat, P.C. Brum, J.H. Brumell, N. Brunetti-Pierri, R.J. BrysonRichardson, S. Buch, A.M. Buchan, H. Budak, D.V. Bulavin, S.J. Bultman, G. Bultynck, V. Bumbasirevic, Y. Burelle, R.E. Burke, M. Burmeister, P. Bütikofer, L. Caberlotto, K. Cadwell, M. Cahova, D. Cai, J. Cai, Q. Cai, S. Calatayud, N. Camougrand, M. Campanella, G.R. Campbell, M. Campbell, S. Campello, R. Candau, I. Caniggia, L. Cantoni, L. Cao, A.B. Caplan, M. Caraglia, C. Cardinali, S.M. Cardoso, J.S. Carew, L.A. Carleton, C.R. Carlin, S. Carloni, S.R. Carlsson, D. Carmona-Gutierrez, L.A. Carneiro, O. Carnevali, S. Carra, A. Carrier, B. Carroll, C. Casas, J. Casas, G. Cassinelli, P. Castets, S. Castro-Obregon, G. Cavallini, I. Ceccherini, F. Cecconi, A.I. Cederbaum, V. Ceña, S. Cenci, C. Cerella, D. Cervia, S. Cetrullo, H. Chaachouay, H.-J. Chae, A.S. Chagin, C.-Y. Chai, G. Chakrabarti, G. Chamilos, E.Y. Chan, M.T. Chan, D. Chandra, P. Chandra, C.-P. Chang, R.C.-C. Chang, T.Y. Chang, J.C. Chatham, S. Chatterjee, S. Chauhan, Y. Che, M.E. Cheetham, R. Cheluvappa, C.-J. Chen, G. Chen, G.-C. Chen, G. Chen, H. Chen, J.W. Chen, J.-K. Chen, M. Chen, M. Chen, P. Chen, Q. Chen, Q. Chen, S.-D. Chen, S. Chen, S.S.-L. Chen, W. Chen, W.-J. Chen, W.Q. Chen, W. Chen, X. Chen, Y.-H. Chen, Y.-G. Chen, Y. Chen, Y. Chen, Y. Chen, Y.-J. Chen, Y.-Q. Chen, Y. Chen, Z. Chen, Z. Chen, A. Cheng, C.H. Cheng, H. Cheng, H. Cheong, S. Cherry, J. Chesney, C.H.A. Cheung, E. Chevet, H.C. Chi, S.-G. Chi, F. Chiacchiera, H.-L. Chiang, R. Chiarelli, M. Chiariello, M. Chieppa, L.-S. Chin, M. Chiong, G.N. Chiu, D.-H. Cho, S.-G. Cho, W.C. Cho, Y.-Y. Cho, Y.-S. Cho, A.M. Choi, E.-J. Choi, E.-K. Choi, J. Choi, M.E. Choi, S.-I. Choi, T.-F. Chou, S. Chouaib, D. Choubey, V. Choubey, K.-C. Chow, K. 
Chowdhury, C.T. Chu, T.-H. Chuang, T. Chun, H. Chung, T. Chung, Y.-L. Chung, Y.-J. Chwae, V. Cianfanelli, R. Ciarcia, I.A. Ciechomska, M.R. Ciriolo, M. Cirone, S. Claerhout, M.J. Clague, J. Clària, P.G. Clarke, R. Clarke, E. Clementi, C. Cleyrat, M. Cnop, E.M. Coccia, T. Cocco, P. Codogno, J. Coers, E.E. Cohen, D. Colecchia, L. Coletto, N.S. Coll, E. Colucci-Guyon, S. Comincini, M. Condello, K.L. Cook, G.H. Coombs, C.D. Cooper, J.M. Cooper, I. Coppens, M.T. Corasaniti, M. Corazzari, R. Corbalan, E. CorcelleTermeau, M.D. Cordero, C. Corral-Ramos, O. Corti, A. Cossarizza, P. Costelli, S. Costes, S.L. Cotman, A. CotoMontes, S. Cottet, E. Couve, L.R. Covey, L.A. Cowart, J.S. Cox, F.P. Coxon, C.B. Coyne, M.S. Cragg, R.J. Craven, T. Crepaldi, J.L. Crespo, A. Criollo, V. Crippa, M.T. Cruz, A.M. Cuervo, J.M. Cuezva, T. Cui, P.R. Cutillas, M.J. Czaja, M.F. Czyzyk-Krzeska, R.K. Dagda, U. Dahmen, C. Dai, W. Dai, Y. Dai, K.N. Dalby, L. Dalla Valle, G. Dalmasso, M. D'Amelio, M. Damme, A. Darfeuille-Michaud, C. Dargemont, V.M. Darley-Usmar, S. Dasarathy, B. Dasgupta, S. Dash, C.R. Dass, H.M. Davey, L.M. Davids, D. Dávila, R.J. Davis, T.M. Dawson, V.L. Dawson, P. Daza, J. de Belleroche, P. de Figueiredo, R.C.B.Q. de Figueiredo, J. de la Fuente, L. De Martino, A. De Matteis, G.R. De Meyer, A. De Milito, M. De Santi, W. de Souza, V. De Tata, D. De Zio, J. Debnath, R. Dechant, J.-P. Decuypere, S. Deegan, B. Dehay, B. Del Bello, D.P. Del Re, R. Delage-Mourroux, L. M. Delbridge, L. Deldicque, E. Delorme-Axford, Y. Deng, J. Dengjel, M. Denizot, P. Dent, C.J. Der, V. Deretic, B. Derrien, E. Deutsch, T.P. Devarenne, R.J. Devenish, S. Di Bartolomeo, N. Di Daniele, F. Di Domenico, A. Di Nardo, S. Di Paola, A. Di Pietro, L. Di Renzo, A. DiAntonio, G. DíazAraya, I. Díaz-Laviada, M.T. Diaz-Meco, J. Diaz-Nido, C.A. Dickey, R.C. Dickson, M. Diederich, P. Digard, I. Dikic, S.P. Dinesh-Kumar, C. Ding, W.-X. Ding, Z. Ding, L. Dini, J.H. Distler, A. Diwan, M. Djavaheri-Mergny, K. Dmytruk, R.C. Dobson, V. Doetsch, K. Dokladny, S. Dokudovskaya, M. Donadelli, X.C. Dong, X. Dong, Z. Dong, T.M. Donohue, K. S. Doran, G. D'Orazi, G.W. Dorn, V. Dosenko, S. Dridi, L. Drucker, J. Du, L.-L. Du, L. Du, A. du Toit, P. Dua, L. Duan, P. Duann, V.K. Dubey, M.R. Duchen, M.A. Duchosal, H. Duez, I. Dugail, V.I. Dumit, M.C. Duncan, E.A. Dunlop, W.A. Dunn, N. Dupont, L. Dupuis, R.V. Durán, T.M. Durcan, S. Duvezin-Caubet, U. Duvvuri, V. Eapen, D. EbrahimiFakhari, A. Echard, L. Eckhart, C.L. Edelstein, A.L. Edinger, L. Eichinger, T. Eisenberg, A. Eisenberg-Lerner, N.T. Eissa, W.S. El-Deiry, V. El-Khoury, Z. Elazar, H. Eldar-Finkelman, C.J. Elliott, E. Emanuele, U. Emmenegger, N. Engedal, A.M. Engelbrecht, S. Engelender, J.M. Enserink, R. Erdmann, J. Erenpreisa, R. Eri, J.L. Eriksen, A. Erman, R. Escalante, E.-L. Eskelinen, L. Espert, L. Esteban-Martínez, T.J. Evans, M. Fabri, G. Fabrias, C. Fabrizi, A. Facchiano, N.J. Færgeman, A. Faggioni, W.D. Fairlie, C. Fan, D. Fan, J. Fan, S. Fang, M. Fanto, A. Fanzani, T. Farkas, M. Faure, F. B. Favier, H. Fearnhead, M. Federici, E. Fei, T.C. Felizardo, H. Feng, Y. Feng, Y. Feng, T.A. Ferguson, Á.F. Fernández, M.G. Fernandez-Barrena, J.C. Fernandez-Checa, A. Fernández-López, M.E. Fernandez-Zapico, O. Feron, E. Ferraro, C.V. Ferreira-Halder, L. Fesus, R. Feuer, F.C. Fiesel, E.C. Filippi-Chiela, G. Filomeni, G.M. Fimia, J.H. Fingert, S. Finkbeiner, T. Finkel, F. Fiorito, P.B. Fisher, M. Flajolet, F. Flamigni, O. Florey, S. Florio, R.A. Floto, M. Folini, C. Follo, E.A. Fon, F. Fornai, F. Fortunato, A. Fraldi, R. Franco, A. Francois, A. François, L.B. Frankel, I.D. Fraser, N. Frey, D.G. Freyssenet, C. Frezza, S.L. Friedman,
D.E. Frigo, D. Fu, J.M. Fuentes, J. Fueyo, Y. Fujitani, Y. Fujiwara, M. Fujiya, M. Fukuda, S. Fulda, C. Fusco, B. Gabryel, M. Gaestel, P. Gailly, M. Gajewska, S. Galadari, G. Galili, I. Galindo, M.F. Galindo, G. Galliciotti, L. Galluzzi, L. Galluzzi, V. Galy, N. Gammoh, S. Gandy, A.K. Ganesan, S. Ganesan, I.G. Ganley, M. Gannagé, F.-B. Gao, F. Gao, J.X. Gao, L. García Nannig, E. García Véscovi, M. GarciaMacía, C. Garcia-Ruiz, A.D. Garg, P.K. Garg, R. Gargini, N. C. Gassen, D. Gatica, E. Gatti, J. Gavard, E. Gavathiotis, L. Ge, P. Ge, S. Ge, P.-W. Gean, V. Gelmetti, A.A. Genazzani, J. Geng, P. Genschik, L. Gerner, J.E. Gestwicki, D.A. Gewirtz, S. Ghavami, E. Ghigo, D. Ghosh, A.M. Giammarioli, F. Giampieri, C. Giampietri, A. Giatromanolaki, D.J. Gibbings, L. Gibellini, S.B. Gibson, V. Ginet, A. Giordano, F. Giorgini, E. Giovannetti, S.E. Girardin, S. Gispert, S. Giuliano, C.L. Gladson, A. Glavic, M. Gleave, N. Godefroy, R.M. Gogal, K. Gokulan, G.H. Goldman, D. Goletti, M.S. Goligorsky, A.V. Gomes, L.C. Gomes, H. Gomez, C. Gomez-Manzano, R. Gómez-Sánchez, D.A. Gonçalves, E. Goncu, Q. Gong, C. Gongora, C.B. Gonzalez, P. Gonzalez-Alegre, P. Gonzalez-Cabo, R.A. González-Polo, I.S. Goping, C. Gorbea, N.V. Gorbunov, D.R. Goring, A.M. Gorman, S.M. Gorski, S. Goruppi, S. Goto-Yamada, C. Gotor, R.A. Gottlieb, I. Gozes, D. Gozuacik, Y. Graba, M. Graef, G.E. Granato, G.D. Grant, S. Grant, G.L. Gravina, D. R. Green, A. Greenhough, M.T. Greenwood, B. Grimaldi, F. Gros, C. Grose, J.-F. Groulx, F. Gruber, P. Grumati, T. Grune, J.-L. Guan, K.-L. Guan, B. Guerra, C. Guillen, K. Gulshan, J. Gunst, C. Guo, L. Guo, M. Guo, W. Guo, X.-G. Guo, A.A. Gust, Å.B. Gustafsson, E. Gutierrez, M.G. Gutierrez, H.-S. Gwak, A. Haas, J.E. Haber, S. Hadano, M. Hagedorn, D.R. Hahn, A.J. Halayko, A. HamacherBrady, K. Hamada, A. Hamai, A. Hamann, M. Hamasaki, I. Hamer, Q. Hamid, E.M. Hammond, F. Han, W. Han, J.T. Handa, J.A. Hanover, M. Hansen, M. Harada, L. HarhajiTrajkovic, J.W. Harper, A.H. Harrath, A.L. Harris, J. Harris, U. Hasler, P. Hasselblatt, K. Hasui, R.G. Hawley, T.S. Hawley, C. He, C.Y. He, F. He, G. He, R.-R. He, X.-H. He, Y.-W. He, Y.-Y. He, J.K. Heath, M.-J. Hébert, R.A. Heinzen, G.V. Helgason, M. Hensel, E.P. Henske, C. Her, P.K. Herman, A. Hernández, C. Hernandez, S. HernándezTiedra, C. Hetz, P.R. Hiesinger, K. Higaki, S. Hilfiker, B.G. Hill, J.A. Hill, W.D. Hill, K. Hino, D. Hofius, P. Hofman, G.U. Höglinger, J. Höhfeld, M.K. Holz, Y. Hong, D.A. Hood, J.J. Hoozemans, T. Hoppe, C. Hsu, C.-Y. Hsu, L.-C. Hsu, D. Hu, G. Hu, H.-M. Hu, H. Hu, M.C. Hu, Y.-C. Hu, Z.-W. Hu, F. Hua, Y. Hua, C. Huang, H.-L. Huang, K.-H. Huang, K.-Y. Huang, S. Huang, S. Huang, W.-P. Huang, Y.-R. Huang, Y. Huang, Y. Huang, T.B. Huber, P. Huebbe, W.-K. Huh, J.J. Hulmi, G.M. Hur, J.H. Hurley, Z. Husak, S.N. Hussain, S. Hussain, J.J. Hwang, S. Hwang, T.I. Hwang, A. Ichihara, Y. Imai, C. Imbriano, M. Inomata, T. Into, V. Iovane, J.L. Iovanna, R.V. Iozzo, N.Y. Ip, J.E. Irazoqui, P. Iribarren, Y. Isaka, A.J. Isakovic, H. Ischiropoulos, J.S. Isenberg, M. Ishaq, H. Ishida, I. Ishii, J.E. Ishmael, C. Isidoro, K.-I. Isobe, E. Isono, S. Issazadeh-Navikas, K. Itahana, E. Itakura, A.I. Ivanov, A.K.V. Iyer, J.M. Izquierdo, Y. Izumi, V. Izzo, M. Jäättelä, N. Jaber, D.J. Jackson, W.T. Jackson, T.G. Jacob, T.S. Jacques, C. Jagannath, A. Jain, N.R. Jana, B.K. Jang, A. Jani, B. Janji, P.R. Jannig, P.J. Jansson, S. Jean, M. Jendrach, J.-H. Jeon, N. Jessen, E.-B. Jeung, K. Jia, L. Jia, $H$. Jiang, $H$. Jiang, L. Jiang, T. Jiang, $X$. Jiang, $X$. Jiang, $X$. Jiang, Y. Jiang, Y. Jiang, A. Jiménez, C. Jin, H. Jin, L. Jin, M. Jin, S. Jin, U.K. Jinwal, E.-K. Jo, T. Johansen, D.E. 
Johnson, G.V. Johnson, J.D. Johnson, E. Jonasch, C. Jones, L.A. Joosten, J. Jordan, A.-M. Joseph, B. Joseph, A. M. Joubert, D. Ju, J. Ju, H.-F. Juan, K. Juenemann, G. Juhász, H.S. Jung, J.U. Jung, Y.-K. Jung, H. Jungbluth, M. J. Justice, B. Jutten, N.O. Kaakoush, K. Kaarniranta, A. Kaasik, T. Kabuta, B. Kaeffer, K. Kågedal, A. Kahana, S. Kajimura, O. Kakhlon, M. Kalia, D.V. Kalvakolanu, Y. Kamada, K. Kambas, V.O. Kaminskyy, H.H. Kampinga, M. Kandouz, C. Kang, R. Kang, T.-C. Kang, T. Kanki, T.-D. Kanneganti, H. Kanno, A.G. Kanthasamy, M. Kantorow, M. Kaparakis-Liaskos, O. Kapuy, V. Karantza, M.R. Karim, P. Karmakar, A. Kaser, S. Kaushik, T. Kawula, A.M. Kaynar, P.-Y. Ke, Z.-J. Ke, J.H. Kehrl, K.E. Keller, J.K. Kemper, A.K. Kenworthy, O. Kepp, A. Kern, S. Kesari, D. Kessel, R. Ketteler, I. do C. Kettelhut, B. Khambu, M.M. Khan, V.K. Khandelwal, S. Khare, J.G. Kiang, A.A. Kiger, A. Kihara, A. L. Kim, C.H. Kim, D.R. Kim, D.-H. Kim, E.K. Kim, H.Y. Kim, H.-R. Kim, J.-S. Kim, J.H. Kim, J.C. Kim, J.H. Kim, K.W. Kim, M.D. Kim, M.-M. Kim, P.K. Kim, S.W. Kim, S.-Y. Kim, Y.-S. Kim, Y. Kim, A. Kimchi, A.C. Kimmelman, T. Kimura, J. S. King, K. Kirkegaard, V. Kirkin, L.A. Kirshenbaum, S. Kishi, Y. Kitajima, K. Kitamoto, Y. Kitaoka, K. Kitazato, R.A. Kley, W.T. Klimecki, M. Klinkenberg, J. Klucken, H. Knævelsrud, E. Knecht, L. Knuppertz, J.-L. Ko, S. Kobayashi, J.C. Koch, C. Koechlin-Ramonatxo, U. Koenig, Y.H. Koh, K. Köhler, S.D. Kohlwein, M. Koike, M. Komatsu, E. Kominami, D. Kong, H.J. Kong, E.G. Konstantakou, B.T. Kopp, T. Korcsmaros, L. Korhonen, V.I. Korolchuk, N.V. Koshkina, Y. Kou, M.I. Koukourakis, C. Koumenis, A.L. Kovács, T. Kovács, W.J. Kovacs, D. Koya, C. Kraft, D. Krainc, H. Kramer, T. Kravic-Stevovic, W. Krek, C. KretzRemy, R. Krick, M. Krishnamurthy, J. Kriston-Vizi, G. Kroemer, M.C. Kruer, R. Kruger, N.T. Ktistakis, K. Kuchitsu, C. Kuhn, A.P. Kumar, A. Kumar, A. Kumar, D. Kumar, D. Kumar, R. Kumar, S. Kumar, M. Kundu, H.-J. Kung, A. Kuno, S.-H. Kuo, J. Kuret, T. Kurz, T. Kwok, T.K. Kwon, Y.T. Kwon, I. Kyrmizi, A.R. La Spada, F. Lafont, T. Lahm, A. Lakkaraju, T. Lam, T. Lamark, S. Lancel, T.H. Landowski, D.J.R. Lane, J.D. Lane, C. Lanzi, P. Lapaquette, L.R. Lapierre, J. Laporte, J. Laukkarinen, G.W. Laurie, S. Lavandero, L. Lavie, M.J. LaVoie, B.Y.K. Law, H.K.-W. Law, K.B. Law, R. Layfield, P.A. Lazo, L. Le Cam, K.G. Le Roch, H. Le Stunff, V. Leardkamolkarn, M. Lecuit, B.-H. Lee, C.-H. Lee, E.F. Lee, G.M. Lee, H.-J. Lee, H. Lee, J.K. Lee, J. Lee, J.-H. Lee, J.H. Lee, M. Lee, M.-S. Lee, P.J. Lee, S.W. Lee, S.-J. Lee, S.-J. Lee, S.Y. Lee, S.H. Lee, S.S. Lee, S.-J. Lee, S. Lee, Y.-R. Lee, Y.J. Lee, Y.H. Lee, C. Leeuwenburgh, S. Lefort, R. Legouis, J. Lei, Q.-Y. Lei, D.A. Leib, G. Leibowitz, I. Lekli, S.D. Lemaire, J.J. Lemasters, M. K. Lemberg, A. Lemoine, S. Leng, G. Lenz, P. lenzi, L.O. Lerman, D. Lettieri Barbato, J.I.-J. Leu, H.Y. Leung, B. Levine, P.A. Lewis, F. Lezoualc'h, C. Li, F. Li, F.-J. Li, J. Li, K. Li, L. Li, M. Li, M. Li, Q. Li, R. Li, S. Li, W. Li, W. Li, X. Li, Y. Li, J. Lian, C. Liang, Q. Liang, Y. Liao, J. Liberal, P.P. Liberski, P. Lie, A.P. Lieberman, H.J. Lim, K.-L. Lim, K. Lim, R.T. Lima, C.-S. Lin, C.-F. Lin, F. Lin, F. Lin, F.-C. Lin, K. Lin, K.-H. Lin, P.-H. Lin, T. Lin, W.-W. Lin, Y.-S. Lin, Y. Lin, R. Linden, D. Lindholm, L.M. Lindqvist, P. Lingor, A. Linkermann, L.A. Liotta, M.M. Lipinski, V.A. Lira, M.P. Lisanti, P.B. Liton, B. Liu, C. Liu, C.-F. Liu, F. Liu, H.-J. Liu, J. Liu, J.-J. Liu, J.-L. Liu, K. Liu, L. Liu, L. Liu, Q. Liu, R.-Y. Liu, S. Liu, S. Liu, W. Liu, X.-D. Liu, X. Liu, X.-H. Liu, X. Liu, X. Liu, X. Liu, Y. Liu, Y. Liu, Z. Liu, Z. Liu, J.P. Liuzzi, G. Lizard, M. Ljujic, I. J. Lodhi, S.E. Logue, B.L. Lokeshwar, Y.C. Long, S. Lonial,
B. Loos, C. López-Otín, C. López-Vicario, M. Lorente, P.L. Lorenzi, P. Lõrincz, M. Los, M.T. Lotze, P.E. Lovat, B. Lu, B. Lu, J. Lu, Q. Lu, S.-M. Lu, S. Lu, Y. Lu, F. Luciano, S. Luckhart, J.M. Lucocq, P. Ludovico, A. Lugea, N.W. Lukacs, J.J. Lum, A.H. Lund, H. Luo, J. Luo, S. Luo, C. Luparello, T. Lyons, J. Ma, Y. Ma, Y. Ma, Z. Ma, J. Machado, G.M. Machado-Santelli, F. Macian, G.C. MacIntosh, J.P. MacKeigan, K.F. Macleod, J.D. MacMicking, L.A. MacMillanCrow, F. Madeo, M. Madesh, J. Madrigal-Matute, A. Maeda, T. Maeda, G. Maegawa, E. Maellaro, H. Maes, M. Magariños, K. Maiese, T.K. Maiti, L. Maiuri, M.C. Maiuri, C.G. Maki, R. Malli, W. Malorni, A. Maloyan, F. MamiChouaib, N. Man, J.D. Mancias, E.-M. Mandelkow, M.A. Mandell, A.A. Manfredi, S.N. Manié, C. Manzoni, K. Mao, Z. Mao, Z.-W. Mao, P. Marambaud, A.M. Marconi, Z. Marelja, G. Marfe, M. Margeta, E. Margittai, M. Mari, F.V. Mariani, C. Marin, S. Marinelli, G. Mariño, I. Markovic, R. Marquez, A.M. Martelli, S. Martens, K.R. Martin, S.J. Martin, S. Martin, M.A. Martin-Acebes, P. Martín-Sanz, C. Martinand-Mari, W. Martinet, J. Martinez, N. Martinez-Lopez, U. MartinezOutschoorn, M. Martínez-Velázquez, M. Martinez-Vicente, W.K. Martins, H. Mashima, J.A. Mastrianni, G. Matarese, P. Matarrese, R. Mateo, S. Matoba, N. Matsumoto, T. Matsushita, A. Matsuura, T. Matsuzawa, M.P. Mattson, S. Matus, N. Maugeri, C. Mauvezin, A. Mayer, D. Maysinger, G.D. Mazzolini, M.K. McBrayer, K. McCall, C. McCormick, G.M. Mclnerney, S.C. Mclver, S. McKenna, J.J. McMahon, I.A. McNeish, F. Mechta-Grigoriou, J.P. Medema, D.L. Medina, K. Megyeri, M. Mehrpour, J.L. Mehta, Y. Mei, U.-C. Meier, A.J. Meijer, A. Meléndez, G. Melino, S. Melino, E.J.T. de Melo, M.A. Mena, M.D. Meneghini, J.A. Menendez, R. Menezes, L. Meng, L.-H. Meng, S. Meng, R. Menghini, A.S. Menko, R.F. Menna-Barreto, M.B. Menon, M.A. MerazRíos, G. Merla, L. Merlini, A.M. Merlot, A. Meryk, S. Meschini, J.N. Meyer, M.-T. Mi, C.-Y. Miao, L. Micale, S. Michaeli, C. Michiels, A.R. Migliaccio, A.S. Mihailidou, D. Mijaljica, K. Mikoshiba, E. Milan, L. Miller-Fleming, G.B. Mills, I.G. Mills, G. Minakaki, B.A. Minassian, X.-F. Ming, F. Minibayeva, E.A. Minina, J.D. Mintern, S. Minucci, A. Miranda-Vizuete, C.H. Mitchell, S. Miyamoto, K. Miyazawa, N. Mizushima, K. Mnich, B. Mograbi, S. Mohseni, L.F. Moita, M. Molinari, M. Molinari, A.B. Møller, B. Mollereau, F. Mollinedo, M. Mongillo, M.M. Monick, S. Montagnaro, C. Montell, D.J. Moore, M.N. Moore, R. Mora-Rodriguez, P.I. Moreira, E. Morel, M.B. Morelli, S. Moreno, M.J. Morgan, A. Moris, Y. Moriyasu, J.L. Morrison, L.A. Morrison, E. Morselli, J. Moscat, P.L. Moseley, S. Mostowy, E. Motori, D. Mottet, J. C. Mottram, C.E.-H. Moussa, V.E. Mpakou, H. Mukhtar, J. M. Mulcahy Levy, S. Muller, R. Muñoz-Moreno, C. MuñozPinedo, C. Münz, M.E. Murphy, J.T. Murray, A. Murthy, I.U. Mysorekar, I.R. Nabi, M. Nabissi, G.A. Nader, Y. Nagahara, Y. Nagai, K. Nagata, A. Nagelkerke, P. Nagy, S.R. Naidu, S. Nair, H. Nakano, H. Nakatogawa, M. Nanjundan, G. Napolitano, N.I. Naqvi, R. Nardacci, D.P. Narendra, M. Narita, A.C. Nascimbeni, R. Natarajan, L.C. Navegantes, S. T. Nawrocki, T.Y. Nazarko, V.Y. Nazarko, T. Neill, L.M. Neri, M.G. Netea, R.T. Netea-Maier, B.M. Neves, P.A. Ney, I.P. Nezis, H.T. Nguyen, H.P. Nguyen, A.-S. Nicot, H. Nilsen, P. Nilsson, M. Nishimura, I. Nishino, M. Niso-Santano, H. Niu, R.A. Nixon, V.C. Njar, T. Noda, A.A. Noegel, E.M. Nolte, E. Norberg, K.K. Norga, S.K. Noureini, S. Notomi, L. Notterpek, K. Nowikovsky, N. Nukina, T. Nürnberger, V.B. O'Donnell, T. O'Donovan, P.J. O'Dwyer, I. Oehme, C.L. Oeste, M. Ogawa, B. Ogretmen, Y. Ogura, Y.J. Oh, M. 
Ohmuraya, T. Ohshima, R. Ojha, K. Okamoto, T. Okazaki, F.J. Oliver, K. Ollinger, S. Olsson, D.P. Orban, P. Ordonez, I. Orhon, L. Orosz, E.J. O'Rourke, H. Orozco, A.L. Ortega, E. Ortona, L.D. Osellame, J. Oshima, S. Oshima, H.D. Osiewacz, T. Otomo, K. Otsu, J.-H.J. Ou, T.F. Outeiro, D.-Y. Ouyang, H. Ouyang, M. Overholtzer, M.A. Ozbun, P.H. Ozdinler, B. Ozpolat, C. Pacelli, P. Paganetti, G. Page, G. Pages, U. Pagnini, B. Pajak, S.C. Pak, K. Pakos-Zebrucka, N. Pakpour, Z. Palková, F. Palladino, K. Pallauf, N. Pallet, M. Palmieri, S.R. Paludan, C. Palumbo, S. Palumbo, O. Pampliega, H. Pan, W. Pan, T. Panaretakis, A. Pandey, A. Pantazopoulou, Z. Papackova, D.L. Papademetrio, I. Papassideri, A. Papini, N. Parajuli, J. Pardo, V.V. Parekh, G. Parenti, J.-I. Park, J. Park, O.K. Park, R. Parker, R. Parlato, J.B. Parys, K.R. Parzych, J.-M. Pasquet, B. Pasquier, K.B. Pasumarthi, D. Patschan, C. Patterson, S. Pattingre, S. Pattison, A. Pause, H. Pavenstädt, F. Pavone, Z. Pedrozo, F.J. Peña, M.A. Peñalva, M. Pende, J. Peng, F. Penna, J.M. Penninger, A. Pensalfini, S. Pepe, G.J. Pereira, P.C. Pereira, V. Pérez-de la Cruz, M.E. Pérez-Pérez, D. Pérez-Rodríguez, D. Pérez-Sala, C. Perier, A. Perl, D.H. Perlmutter, I. Perrotta, S. Pervaiz, M. Pesonen, J.E. Pessin, G.J. Peters, M. Petersen, I. Petrache, B.J. Petrof, G. Petrovski, J.M. Phang, M. Piacentini, M. Pierdominici, P. Pierre, V. Pierrefite-Carle, F. Pietrocola, F.X. PimentelMuiños, M. Pinar, B. Pineda, R. Pinkas-Kramarski, M. Pinti, P. Pinton, B. Piperdi, J.M. Piret, L.C. Platanias, H.W. Platta, E.D. Plowey, S. Pöggeler, M. Poirot, P. Polčic, A. Poletti, A. H. Poon, H. Popelka, B. Popova, I. Poprawa, S.M. Poulose, J. Poulton, S.K. Powers, T. Powers, M. Pozuelo-Rubio, K. Prak, R. Prange, M. Prescott, M. Priault, S. Prince, R.L. Proia, T. Proikas-Cezanne, H. Prokisch, V.J. Promponas, K. Przyklenk, R. Puertollano, S. Pugazhenthi, L. Puglielli, A. Pujol, J. Puyal, D. Pyeon, X. Qi, W.-B. Qian, Z.-H. Qin, Y. Qiu, Z. Qu, J. Quadrilatero, F. Quinn, N. Raben, H. Rabinowich, F. Radogna, M.J. Ragusa, M. Rahmani, K. Raina, S. Ramanadham, R. Ramesh, A. Rami, S. RandallDemllo, F. Randow, H. Rao, V.A. Rao, B.B. Rasmussen, T. M. Rasse, E.A. Ratovitski, P.-E. Rautou, S.K. Ray, B. Razani, B.H. Reed, F. Reggiori, M. Rehm, A.S. Reichert, T. Rein, D.J. Reiner, E. Reits, J. Ren, X. Ren, M. Renna, J.E. Reusch, J.L. Revuelta, L. Reyes, A.R. Rezaie, R.I. Richards, D.R. Richardson, C. Richetta, M.A. Riehle, B.H. Rihn, Y. Rikihisa, B.E. Riley, G. Rimbach, M.R. Rippo, K. Ritis, F. Rizzi, E. Rizzo, P.J. Roach, J. Robbins, M. Roberge, G. Roca, M.C. Roccheri, S. Rocha, C.M. Rodrigues, C.I. Rodríguez, S.R. de Cordoba, N. Rodriguez-Muela, J. Roelofs, V.V. Rogov, T.T. Rohn, B. Rohrer, D. Romanelli, L. Romani, P.S. Romano, M.I.G. Roncero, J.L. Rosa, A. Rosello, K.V. Rosen, P. Rosenstiel, M. Rost-Roszkowska, K.A. Roth, G. Roué, M. Rouis, K.M. Rouschop, D.T. Ruan, D. Ruano, D.C. Rubinsztein, E.B. Rucker, A. Rudich, E. Rudolf, R. Rudolf, M.A. Ruegg, C. Ruiz-Roldan, A.A. Ruparelia, P. Rusmini, D.W. Russ, G.L. Russo, G. Russo, R. Russo, T.E. Rusten, V. Ryabovol, K.M. Ryan, S.W. Ryter, D.M. Sabatini, M. Sacher, C. Sachse, M. N. Sack, J. Sadoshima, P. Saftig, R. Sagi-Eisenberg, S. Sahni, P. Saikumar, T. Saito, T. Saitoh, K. Sakakura, M. Sakoh-Nakatogawa, Y. Sakuraba, M. Salazar-Roa, P. Salomoni, A.K. Saluja, P.M. Salvaterra, R. Salvioli, A. Samali, A.M. Sanchez, J.A. Sánchez-Alcázar, R. SanchezPrieto, M. Sandri, M.A. Sanjuan, S. Santaguida, L. Santambrogio, G. Santoni, C.N. Dos Santos, S. Saran, M. Sardiello, G. Sargent, P. Sarkar, S. Sarkar, M.R. Sarrias, M.
M. Sarwal, C. Sasakawa, M. Sasaki, M. Sass, K. Sato, M. Sato, J. Satriano, N. Savaraj, S. Saveljeva, L. Schaefer, U. E. Schaible, M. Scharl, H.M. Schatzl, R. Schekman, W. Scheper, A. Schiavi, H.M. Schipper, H. Schmeisser, J. Schmidt, I. Schmitz, B.E. Schneider, E.M. Schneider, J.L. Schneider, E.A. Schon, M.J. Schönenberger, A.H. Schönthal, D.F. Schorderet, B. Schröder, S. Schuck, R.J. Schulze, M. Schwarten, T.L. Schwarz, S. Sciarretta, K. Scotto, A.I. Scovassi, R.A. Screaton, M. Screen, H. Seca, S. Sedej, L. Segatori, N. Segev, P.O. Seglen, J.M. SeguíSimarro, J. Segura-Aguilar, E. Seki, C. Sell, I. Seiliez, C.F. Semenkovich, G.L. Semenza, U. Sen, A.L. Serra, A. Serrano-Puebla, H. Sesaki, T. Setoguchi, C. Settembre, J. J. Shacka, A.N. Shajahan-Haq, I.M. Shapiro, S. Sharma, H. She, C.-K.J. Shen, C.-C. Shen, H.-M. Shen, S. Shen, W. Shen, R. Sheng, X. Sheng, Z.-H. Sheng, T.G. Shepherd, J. Shi, Q. Shi, Q. Shi, Y. Shi, S. Shibutani, K. Shibuya, Y. Shidoji, J.-J. Shieh, C.-M. Shih, Y. Shimada, S. Shimizu, D. W. Shin, M.L. Shinohara, M. Shintani, T. Shintani, T. Shioi, K. Shirabe, R. Shiri-Sverdlov, O. Shirihai, G.C. Shore, C.-W. Shu, D. Shukla, A.A. Sibirny, V. Sica, C.J. Sigurdson, E.M. Sigurdsson, P.S. Sijwali, B. Sikorska, W.A. Silveira, S. Silvente-Poirot, G.A. Silverman, J. Simak, T. Simmet, A.K. Simon, H.-U. Simon, C. Simone, M. Simons, A. Simonsen, R. Singh, S.V. Singh, S.K. Singh, D. Sinha, S. Sinha, F.A. Sinicrope, A. Sirko, K. Sirohi, B.J. Sishi, A. Sittler, P.M. Siu, E. Sivridis, A. Skwarska, R. Slack, I. Slaninová, N. Slavov, S.S. Smaili, K.S. Smalley, D.R. Smith, S.J. Soenen, S.A. Soleimanpour, A. Solhaug, K. Somasundaram, J.H. Son, A. Sonawane, C. Song, F. Song, H.K. Song, J.-X. Song, W. Song, K.Y. Soo, A.K. Sood, T.W. Soong, V. Soontornniyomkij, M. Sorice, F. Sotgia, D.R. Soto-Pantoja, A. Sotthibundhu, M.J. Sousa, H.P. Spaink, P.N. Span, A. Spang, J.D. Sparks, P.G. Speck, S.A. Spector, C.D. Spies, W. Springer, D.S. Clair, A. Stacchiotti, B. Staels, M.T. Stang, D.T. Starczynowski, P. Starokadomskyy, C. Steegborn, J.W. Steele, L. Stefanis, J. Steffan, C.M. Stellrecht, H. Stenmark, T.M. Stepkowski, S.T. Stern, C. Stevens, B.R. Stockwell, V. Stoka, Z. Storchova, B. Stork, V. Stratoulias, D.J. Stravopodis, P. Strnad, A.M. Strohecker, A.-L. Ström, P. Stromhaug, J. Stulik, Y.-X. Su, Z. Su, C.S. Subauste, S. Subramaniam, C.M. Sue, S.W. Suh, X. Sui, S. Sukseree, D. Sulzer, F.-L. Sun, J. Sun, J. Sun, S.-Y. Sun, Y. Sun, Y. Sun, Y. Sun, V. Sundaramoorthy, J. Sung, H. Suzuki, K. Suzuki, N. Suzuki, T. Suzuki, Y.J. Suzuki, M.S. Swanson, C. Swanton, K. Swärd, G. Swarup, S.T. Sweeney, P.W. Sylvester, Z. Szatmari, E. Szegezdi, P.W. Szlosarek, H. Taegtmeyer, M. Tafani, E. Taillebourg, S.W. Tait, K. Takacs-Vellai, Y. Takahashi, S. Takáts, G. Takemura, N. Takigawa, N.J. Talbot, E. Tamagno, J. Tamburini, C.-P. Tan, L. Tan, M.L. Tan, M. Tan, Y.-J. Tan, K. Tanaka, M. Tanaka, D. Tang, D. Tang, G. Tang, I. Tanida, K. Tanji, B.A. Tannous, J.A. Tapia, I. Tasset-Cuevas, M. Tatar, I. Tavassoly, N. Tavernarakis, A. Taylor, G.S. Taylor, G.A. Taylor, J.P. Taylor, M.J. Taylor, E.V. Tchetina, A.R. Tee, F. Teixeira-Clerc, S. Telang, T. Tencomnao, B.-B. Teng, R.-J. Teng, F. Terro, G. Tettamanti, A.L. Theiss, A.E. Theron, K.J. Thomas, M.P. Thomé, P.G. Thomes, A. Thorburn, J. Thorner, T. Thum, M. Thumm, T.L. Thurston, L. Tian, A. Till, J.P.-Y. Ting, V.I. Titorenko, L. Toker, S. Toldo, S.A. Tooze, I. Topisirovic, M.L. Torgersen, L. Torosantucci, A. Torriglia, M.R. Torrisi, C. Tournier, R. Towns, V. Trajkovic, L.H. Travassos, G. Triola, D.N. Tripathi, D. Trisciuoglio, R. Troncoso, I.P. Trougakos, A.C. Truttmann, K.-J. Tsai, M.P. 
Tschan, Y.-H. Tseng, T. Tsukuba, A. Tsung, A.S. Tsvetkov, S. Tu, H.-Y. Tuan, M. Tucci, D.A. Tumbarello, B. Turk, V. Turk, R.F. Turner, A.A. Tveita, S.C. Tyagi, M. Ubukata, Y. Uchiyama, A. Udelnow, T. Ueno, M. Umekawa, R. Umemiya-Shirafuji, B.R. Underwood, C. Ungermann, R.P. Ureshino, R. Ushioda, V.N. Uversky, N.L. Uzcátegui, T. Vaccari, M.I. Vaccaro, L. Váchová, H. VakifahmetogluNorberg, R. Valdor, E.M. Valente, F. Vallette, A.M. Valverde, G. Van den Berghe, L. Van Den Bosch, G.R. van den Brink, F.G. van der Goot, I.J. van der Klei, L.J. van der Laan, W.G. van Doorn, M. van Egmond, K.L. van Golen, L. Van Kaer, M. van Lookeren Campagne, P. Vandenabeele, W. Vandenberghe, I. Vanhorebeek, I. Varela-Nieto, M.H. Vasconcelos, R. Vasko, D.G. Vavvas, I. Vega-Naredo, G. Velasco, A.D. Velentzas, P.D. Velentzas, T. Vellai, E. Vellenga, M.H. Vendelbo, K. Venkatachalam, N. Ventura, S. Ventura, P.S. Veras, M. Verdier, B.G. Vertessy, A. Viale, M. Vidal, H.L.A. Vieira, R.D. Vierstra, N. Vigneswaran, N. Vij, M. Vila, M. Villar, V.H. Villar, J. Villarroya, C. Vindis, G. Viola, M.T. Viscomi, G. Vitale, D.T. Vogl, O.V. Voitsekhovskaja, C. von Haefen, K. von Schwarzenberg, D.E. Voth, V. Vouret-Craviari, K. Vuori, J.M. Vyas, C. Waeber, C.L. Walker, M.J. Walker, J. Walter, L. Wan, X. Wan, B. Wang, C. Wang, C.-Y. Wang, C. Wang, C. Wang, C. Wang, D. Wang, F. Wang, F. Wang, G. Wang, H.-J. Wang, H. Wang, H.-G. Wang, H. Wang, H.-D. Wang, J. Wang, J. Wang, M. Wang, M.-Q. Wang, P.-Y. Wang, P. Wang, R.C. Wang, S. Wang, T.-F. Wang, X. Wang, X.-J. Wang, X.-W. Wang, X. Wang, X. Wang, Y. Wang, Y. Wang, Y. Wang, Y.-J. Wang, Y. Wang, Y. Wang, Y.T. Wang, Y. Wang, Z.-N. Wang, P. Wappner, C. Ward, D.M. Ward, G. Warnes, H. Watada, Y. Watanabe, K. Watase, T.E. Weaver, C.D. Weekes, J. Wei, T. Weide, C.C. Weihl, G. Weindl, S.N. Weis, L. Wen, X. Wen, Y. Wen, B. Westermann, C.M. Weyand, A.R. White, E. White, J.L. Whitton, A.J. Whitworth, J. Wiels, F. Wild, M. E. Wildenberg, T. Wileman, D.S. Wilkinson, S. Wilkinson, D. Willbold, C. Williams, K. Williams, P.R. Williamson, K.F. Winklhofer, S.S. Witkin, S.E. Wohlgemuth, T. Wollert, E.J. Wolvetang, E. Wong, G.W. Wong, R.W. Wong, V.K.W Wong, E.A. Woodcock, K.L. Wright, C. Wu, D. Wu, G.S. Wu, J. Wu, J. Wu, M. Wu, M. Wu, S. Wu, W.K. Wu, Y. Wu, Z. Wu, C.P. Xavier, R.J. Xavier, G.-X. Xia, T. Xia, W. Xia, Y. Xia, H. Xiao, J. Xiao, S. Xiao, W. Xiao, C.-M. Xie, Z. Xie, Z. Xie, M. Xilouri, Y. Xiong, C. Xu, C. Xu, F. Xu, H. Xu, H. Xu, J. Xu, J. Xu, J. Xu, L. Xu, X. Xu, Y. Xu, Y. Xu, Z.-X. Xu, Z. Xu, Y. Xue, T. Yamada, A. Yamamoto, K. Yamanaka, S. Yamashina, S. Yamashiro, B. Yan, B. Yan, X. Yan, Z. Yan, Y. Yanagi, D.-S. Yang, J.-M. Yang, L. Yang, M. Yang, P.-M. Yang, P. Yang, Q. Yang, W. Yang, W.Y. Yang, X. Yang, Y. Yang, Y. Yang, Z. Yang, Z. Yang, M.-C. Yao, P.J. Yao, X. Yao, Z. Yao, Z. Yao, L.S. Yasui, M. Ye, B. Yedvobnick, B. Yeganeh, E.S. Yeh, P.L. Yeyati, F. Yi, L. Yi, X.-M. Yin, C.K. Yip, Y.-M. Yoo, Y.H. Yoo, S.-Y. Yoon, K.-I. Yoshida, T. Yoshimori, K.H. Young, H. Yu, J.J. Yu, J.-T. Yu, J. Yu, L. Yu, W.H. Yu, X.-F. Yu, Z. Yu, J. Yuan, Z.-M. Yuan, B.Y. Yue, J. Yue, Z. Yue, D. N. Zacks, E. Zacksenhaus, N. Zaffaroni, T. Zaglia, Z. Zakeri, V. Zecchini, J. Zeng, M. Zeng, Q. Zeng, A.S. Zervos, D.D. Zhang, F. Zhang, G. Zhang, G.-C. Zhang, H. Zhang, H. Zhang, H. Zhang, H. Zhang, J. Zhang, J. Zhang, J. Zhang, J. Zhang, J.-P. Zhang, L. Zhang, L. Zhang, L. Zhang, L. Zhang, M.-Y. Zhang, X. Zhang, X.D. Zhang, Y. Zhang, Y. Zhang, Y. Zhang, Y. Zhang, Y. Zhang, M. Zhao, W.-L. Zhao, X. Zhao, Y.G. Zhao, Y. Zhao, Y. Zhao, Y.-X. Zhao, Z. Zhao, Z.J. Zhao, D. Zheng, X.-L. Zheng, X. Zheng, B. Zhivotovsky,
Q. Zhong, G.-Z. Zhou, G. Zhou, H. Zhou, S.-F. Zhou, X.-J. Zhou, H. Zhu, H. Zhu, W.-G. Zhu, W. Zhu, X.-F. Zhu, Y. Zhu, S.-M. Zhuang, X. Zhuang, E. Ziparo, C.E. Zois, T. Zoladek, W.-X. Zong, A. Zorzano, S.M. Zughaier, Guidelines for the use and interpretation of assays for monitoring autophagy (3rd edition), Autophagy. 12 (2016) 1-222. doi:https://doi. org/10.1080/15548627.2015.1100356.

[24] K. Takeshige, M. Baba, S. Tsuboi, T. Noda, Y. Ohsumi, Autophagy in yeast demonstrated with proteinase-deficient mutants and conditions for its induction, J. Cell Biol. 119 (1992) 301-311, https://doi.org/10.1083/jcb.119.2.301.

[25] M. Tsukada, Y. Ohsumi, Isolation and characterization of autophagy-defective mutants of Saccharomyces cerevisiae, FEBS Lett. 333 (1993) 169-174.

[26] M. Schlumpberger, E. Schaeffeler, M. Straub, M. Bredschneider, D.H. Wolf, M. Thumm, AUT1, a gene essential for autophagocytosis in the yeast Saccharomyces cerevisiae, J. Bacteriol. 179 (1997) 1068-1076, https://doi. org/10.1128/jb.179.4.1068-1076.1997.

[27] T.M. Harding, A. Hefner-Gravink, M. Thumm, D.J. Klionsky, Genetic and phenotypic overlap between autophagy and the cytoplasm to vacuole protein targeting pathway, J. Biol. Chem. 271 (1996) 17621-17624, https://doi.org/10.1074/ jbc.271.30.17621.

[28] M. Thumm, R. Egner, B. Koch, M. Schlumpberger, M. Straub, M. Veenhuis, D.H. Wolf, Isolation of autophagocytosis mutants of Saccharomyces cerevisiae, FEBS Lett. 349 (1994) 275-280.

[29] N. Mizushima, H. Sugita, T. Yoshimori, Y. Ohsumi, A new protein conjugation system in human. The counterpart of the yeast Apg12p conjugation system essential for autophagy, J. Biol. Chem. 273 (1998) 33889-33892, https://doi. org/10.1074/jbc.273.51.33889.

[30] N. Mizushima, A. Yamamoto, M. Matsui, T. Yoshimori, Y. Ohsumi, In vivo analysis of autophagy in response to nutrient starvation using transgenic mice expressing a fluorescent autophagosome marker, Mol. Biol. Cell 15 (2004) 1101-1111, https://doi.org/10.1091/mbc.E03-09-0704.

[31] Y. Kabeya, N. Mizushima, T. Ueno, A. Yamamoto, T. Kirisako, T. Noda, E. Kominami, Y. Ohsumi, T. Yoshimori, LC3, a mammalian homologue of yeast Apg8p, is localized in autophagosome membranes after processing, EMBO J. 19 (2000) 5720-5728, https://doi.org/10.1093/emboj/19.21.5720.

[32] X.H. Liang, S. Jackson, M. Seaman, K. Brown, B. Kempkes, $\mathrm{H}$. Hibshoosh, B. Levine, Induction of autophagy and inhibition of tumorigenesis by beclin 1, Nature. 402 (1999) 672-676, https://doi.org/10.1038/45257.

[33] M. Mehrpour, A. Esclatine, I. Beau, P. Codogno, Overview of macroautophagy regulation in mammalian cells, Cell Res. 20 (2010) 748-762, https://doi.org/10.1038/cr. 2010.82

[34] Y. Feng, D. He, Z. Yao, D.J. Klionsky, The machinery of macroautophagy, Cell Res. 24 (2014) 24-41, https://doi. org/10.1038/cr.2013.168.

[35] I. Tanida, Y. Sou, J. Ezaki, N. Minematsu-lkeguchi, T. Ueno, E. Kominami, HsAtg4B/HsApg4B/autophagin-1 cleaves the carboxyl termini of three human Atg8 homologues and delipidates microtubule-associated protein light chain 3and GABAA receptor-associated protein-phospholipid conjugates, J. Biol. Chem. 279 (2004) 36268-36276, https:// doi.org/10.1074/jbc.M401461200.

[36] G. Bjørkøy, T. Lamark, A. Brech, H. Outzen, M. Perander, A. Overvatn, H. Stenmark, T. Johansen, p62/SQSTM1 forms protein aggregates degraded by autophagy and has a 
protective effect on huntingtin-induced cell death, J. Cell Biol. 171 (2005) 603-614, https://doi.org/10.1083/jcb. 200507002.

[37] M. Komatsu, S. Waguri, T. Chiba, S. Murata, J. Iwata, I. Tanida, T. Ueno, M. Koike, Y. Uchiyama, E. Kominami, K. Tanaka, Loss of autophagy in the central nervous system causes neurodegeneration in mice, Nature. 441 (2006) 880-884, https://doi.org/10.1038/nature04723.

[38] M. Komatsu, S. Waguri, T. Ueno, J. Iwata, S. Murata, I. Tanida, J. Ezaki, N. Mizushima, Y. Ohsumi, Y. Uchiyama, E. Kominami, K. Tanaka, T. Chiba, Impairment of starvationinduced and constitutive autophagy in Atg7-deficient mice, J. Cell Biol. 169 (2005) 425-434, https://doi.org/10.1083/ jcb.200412022.

[39] T. Hara, K. Nakamura, M. Matsui, A. Yamamoto, Y. Nakahara, R. Suzuki-Migishima, M. Yokoyama, K. Mishima, I. Saito, H. Okano, N. Mizushima, Suppression of basal autophagy in neural cells causes neurodegenerative disease in mice, Nature. 441 (2006) 885-889, https:// doi.org/10.1038/nature04724.

[40] A. Nakai, O. Yamaguchi, T. Takeda, Y. Higuchi, S. Hikoso, M. Taniike, S. Omiya, I. Mizote, Y. Matsumura, M. Asahi, K. Nishida, M. Hori, N. Mizushima, K. Otsu, The role of autophagy in cardiomyocytes in the basal state and in response to hemodynamic stress, Nat. Med. 13 (2007) 619-624, https://doi.org/10.1038/nm1574.

[41] H.S. Jung, K.W. Chung, J. Won Kim, J. Kim, M. Komatsu, K. Tanaka, Y.H. Nguyen, T.M. Kang, K.-H. Yoon, J.-W. Kim, Y. T. Jeong, M.S. Han, M.-K. Lee, K.-W. Kim, J. Shin, M.-S. Lee, Loss of autophagy diminishes pancreatic beta cell mass and function with resultant hyperglycemia, Cell Metab. 8 (2008) 318-324, https://doi.org/10.1016/j.cmet. 2008.08.013.

[42] C. Ebato, T. Uchida, M. Arakawa, M. Komatsu, T. Ueno, K. Komiya, K. Azuma, T. Hirose, K. Tanaka, E. Kominami, R. Kawamori, Y. Fujitani, H. Watada, Autophagy is important in islet homeostasis and compensatory increase of beta cell mass in response to high-fat diet, Cell Metab. 8 (2008) 325-332, https://doi.org/10.1016/j.cmet.2008.08.009.

[43] W. Quan, K.Y. Hur, Y. Lim, S.H. Oh, J.-C. Lee, K.H. Kim, G.H. Kim, S.-W. Kim, H.L. Kim, M.-K. Lee, K.-W. Kim, J. Kim, M. Komatsu, M.-S. Lee, Autophagy deficiency in beta cells leads to compromised unfolded protein response and progression from obesity to diabetes in mice, Diabetologia. 55 (2012) 392-403, https://doi.org/10.1007/s00125-011-2350-y.

[44] S.A. Soleimanpour, A.M. Ferrari, J.C. Raum, D.N. Groff, J. Yang, B.A. Kaufman, D.A. Stoffers, Diabetes susceptibility genes $\mathrm{Pdx} 1$ and Clec16a function in a pathway regulating Mitophagy in $\beta$-cells, Diabetes. 64 (2015) 3475-3484, https://doi.org/10.2337/db15-0376.

[45] R.J. Youle, D.P. Narendra, Mechanisms of mitophagy, Nat. Rev. Mol. Cell Biol. 12 (2011) 9-14, https://doi.org/10.1038/ nrm3028.

[46] S.A. Soleimanpour, A. Gupta, M. Bakay, A.M. Ferrari, D.N. Groff, J. Fadista, L.A. Spruce, J.A. Kushner, L. Groop, S.H. Seeholzer, B.A. Kaufman, H. Hakonarson, D.A. Stoffers, The diabetes susceptibility gene Clec16a regulates mitophagy, Cell. 157 (2014) 1577-1590, https://doi.org/10.1016/ j.cell.2014.05.016.

[47] H.-S. Jin, J. Kim, S.-J. Lee, K. Kim, M.J. Go, J.-Y. Lee, H.-J. Lee, J. Song, B.T. Jeon, G.S. Roh, S.-J. Kim, B.-Y. Kim, K.W. Hong, Y.-H. Yoo, B. Oh, Y. Kang, S.-Y. Jeong, The PARK2 gene is involved in the maintenance of pancreatic $\beta$ cell functions related to insulin production and secretion,
Mol. Cell. Endocrinol. 382 (2014) 178-189, https://doi.org/ 10.1016/j.mce.2013.09.031.

[48] A. Hoshino, M. Ariyoshi, Y. Okawa, S. Kaimoto, M. Uchihashi, K. Fukai, E. Iwai-Kanai, K. Ikeda, T. Ueyama, T. Ogata, S. Matoba, Inhibition of p53 preserves Parkinmediated mitophagy and pancreatic $\beta$-cell function in diabetes, Proc. Natl. Acad. Sci. U. S. A. 111 (2014) 3116-3121, https://doi.org/10.1073/pnas.1318951111.

[49] E. Bachar-Wikstrom, J.D. Wikstrom, N. Kaiser, E. Cerasi, G. Leibowitz, Improvement of ER stress-induced diabetes by stimulating autophagy, Autophagy. 9 (2013) 626-628, https://doi.org/10.4161/auto.23642.

[50] A. Mukherjee, D. Morales-Scheihing, P.C. Butler, C. Soto, Type 2 diabetes as a protein misfolding disease, Trends Mol. Med. 21 (2015) 439-449, https://doi.org/10.1016/j. molmed.2015.04.005.

[51] J.F. Rivera, T. Gurlo, M. Daval, C.J. Huang, A.V. Matveyenko, P.C. Butler, S. Costes, Human-IAPP disrupts the autophagy/lysosomal pathway in pancreatic $\beta$-cells: protective role of p62-positive cytoplasmic inclusions, Cell Death Differ. 18 (2011) 415-426, https://doi.org/10.1038/ cdd.2010.111.

[52] N. Shigihara, A. Fukunaka, A. Hara, K. Komiya, A. Honda, T. Uchida, H. Abe, Y. Toyofuku, M. Tamaki, T. Ogihara, T. Miyatsuka, H.J. Hiddinga, S. Sakagashira, M. Koike, Y. Uchiyama, T. Yoshimori, N.L. Eberhardt, Y. Fujitani, H. Watada, Human IAPP-induced pancreatic $\beta$ cell toxicity and its regulation by autophagy, J. Clin. Invest. 124 (2014) 3634-3644, https://doi.org/10.1172/JCl69866.

[53] J.F. Rivera, S. Costes, T. Gurlo, C.G. Glabe, P.C. Butler, Autophagy defends pancreatic $\beta$ cells from human islet amyloid polypeptide-induced toxicity, J. Clin. Invest. 124 (2014) 3489-3500, https://doi.org/10.1172/JCI71981.

[54] J. Kim, H. Cheon, Y.T. Jeong, W. Quan, K.H. Kim, J.M. Cho, Y.-M. Lim, S.H. Oh, S.-M. Jin, J.H. Kim, M.-K. Lee, S. Kim, M. Komatsu, S.-W. Kang, M.-S. Lee, Amyloidogenic peptide oligomer accumulation in autophagy-deficient $\beta$ cells induces diabetes, J. Clin. Invest. 124 (2014) 3311-3324, https://doi.org/10.1172/JCl69625.

[55] T. Gurlo, S. Kim, A.E. Butler, C. Liu, L. Pei, M. Rosenberger, P.C. Butler, Pregnancy in human IAPP transgenic mice recapitulates beta cell stress in type 2 diabetes, Diabetologia. 62 (2019) 1000-1010, https://doi.org/10.1007/ s00125-019-4843-z.

[56] G. Las, S.B. Serada, J.D. Wikstrom, G. Twig, O.S. Shirihai, Fatty acids suppress autophagic turnover in $\beta$-cells, J. Biol. Chem. 286 (2011) 42534-42544, https://doi.org/10.1074/ jbc.M111.242412.

[57] L. Martino, M. Masini, M. Novelli, P. Beffy, M. Bugliani, L. Marselli, P. Masiello, P. Marchetti, V. De Tata, Palmitate activates autophagy in INS-1E $\beta$-cells and in isolated rat and human pancreatic islets, PLoS One 7 (2012), e36188. https://doi.org/10.1371/journal.pone.0036188.

[58] M. Cnop, B. Abdulkarim, G. Bottu, D.A. Cunha, M. IgoilloEsteve, M. Masini, J.-V. Turatsinze, T. Griebel, O. Villate, I. Santin, M. Bugliani, L. Ladriere, L. Marselli, M.I. McCarthy, P. Marchetti, M. Sammeth, D.L. Eizirik, RNA sequencing identifies dysregulation of the human pancreatic islet transcriptome by the saturated fatty acid palmitate, Diabetes. 63 (2014) 1978-1993, https://doi.org/10.2337/ db13-1383.

[59] S.U.R. Mir, N.M. George, L. Zahoor, R. Harms, Z. Guinn, N. E. Sarvetnick, Inhibition of autophagic turnover in $\beta$-cells by fatty acids and glucose leads to apoptotic cell death, J. Biol. 
Chem. 290 (2015) 6071-6085, https://doi.org/10.1074/jbc. M114.605345.

[60] K. Komiya, T. Uchida, T. Ueno, M. Koike, H. Abe, T. Hirose, R. Kawamori, Y. Uchiyama, E. Kominami, Y. Fujitani, H. Watada, Free fatty acids stimulate autophagy in pancreatic $\beta$-cells via JNK pathway, Biochem. Biophys. Res. Commun. 401 (2010) 561-567, https://doi.org/10.1016/j.bbrc.2010. 09.101.

[61] F.P. Zummo, K.S. Cullen, M. Honkanen-Scott, J.A.M. Shaw, P.E. Lovat, C. Arden, Glucagon-like peptide 1 protects pancreatic $\beta$-cells from death by increasing Autophagic flux and restoring lysosomal function, Diabetes. 66 (2017) 1272-1285, https://doi.org/10.2337/db16-1009.

[62] J. Janikiewicz, K. Hanzelka, A. Dziewulska, K. Kozinski, P. Dobrzyn, T. Bernas, A. Dobrzyn, Inhibition of SCD1 impairs palmitate-derived autophagy at the step of autophagosomelysosome fusion in pancreatic $\beta$-cells, J. Lipid Res. 56 (2015) 1901-1911, https://doi.org/10.1194/jlr.M059980.

[63] J. Ji, M. Petropavlovskaia, A. Khatchadourian, J. Patapas, J. Makhlin, L. Rosenberg, D. Maysinger, Type 2 diabetes is associated with suppression of autophagy and lipid accumulation in $\beta$-cells, J. Cell. Mol. Med. 23 (2019) 2890-2900, https://doi.org/10.1111/jcmm.14172.

[64] K.Y. Chu, L. O'Reilly, G. Ramm, T.J. Biden, High-fat diet increases autophagic flux in pancreatic beta cells in vivo and ex vivo in mice, Diabetologia. 58 (2015) 2074-2078, https://doi.org/10.1007/s00125-015-3665-x.

[65] B.C. King, K. Kulak, U. Krus, R. Rosberg, E. Golec, K. Wozniak, M.F. Gomez, E. Zhang, D.J. O'Connell, E. Renström, A.M. Blom, Complement Component C3 Is Highly Expressed in Human Pancreatic Islets and Prevents $\beta$ Cell Death via ATG16L1 Interaction and Autophagy Regulation, Cell Metab. 29 (2019) 202-210.e6. doi:https:// doi.org/10.1016/j.cmet.2018.09.009.

[66] H. Abe, T. Uchida, A. Hara, H. Mizukami, K. Komiya, M. Koike, N. Shigihara, Y. Toyofuku, T. Ogihara, Y. Uchiyama, S. Yagihashi, Y. Fujitani, H. Watada, Exendin-4 improves $\beta$ cell function in autophagy-deficient $\beta$-cells, Endocrinology. 154 (2013) 4512-4524, https://doi.org/10.1210/en.20131578.

[67] M. Masini, M. Bugliani, R. Lupi, S. del Guerra, U. Boggi, F. Filipponi, L. Marselli, P. Masiello, P. Marchetti, Autophagy in human type 2 diabetes pancreatic beta cells, Diabetologia. 52 (2009) 1083-1086, https://doi.org/10.1007/s00125-009$1347-2$.

[68] H. Mizukami, K. Takahashi, W. Inaba, K. Tsuboi, S. Osonoi, T. Yoshida, S. Yagihashi, Involvement of oxidative stressinduced DNA damage, endoplasmic reticulum stress, and autophagy deficits in the decline of $\beta$-cell mass in Japanese type 2 diabetic patients, Diabetes Care 37 (2014) 1966-1974, https://doi.org/10.2337/dc13-2018.

[69] M. Masini, L. Martino, L. Marselli, M. Bugliani, U. Boggi, F. Filipponi, P. Marchetti, V. De Tata, Ultrastructural alterations of pancreatic beta cells in human diabetes mellitus, Diabetes Metab. Res. Rev. 33 (2017). doi:https://doi.org/ 10.1002/dmrr.2894.

[70] S. Bhansali, A. Bhansali, R. Walia, U.N. Saikia, V. Dhawan, Alterations in mitochondrial oxidative stress and Mitophagy in subjects with prediabetes and type 2 diabetes mellitus, Front. Endocrinol. 8 (2017) 347, https://doi.org/10.3389/ fendo.2017.00347.

[71] X. Cheng, X. Ma, Q. Zhu, D. Song, X. Ding, L. Li, X. Jiang, X. Wang, R. Tian, H. Su, Z. Shen, S. Chen, T. Liu, W. Gong, W. Liu, Q. Sun, Pacer Is a Mediator of mTORC1 and GSK3-
TIP60 Signaling in Regulation of Autophagosome Maturation and Lipid Metabolism, Mol. Cell. 73 (2019) 788-802.e7. doi:https://doi.org/10.1016/j.molcel.2018.12.017.

[72] Y.-M. Kim, C.H. Jung, M. Seo, E.K. Kim, J.-M. Park, S.S. Bae, D.-H. Kim, mTORC1 phosphorylates UVRAG to negatively regulate autophagosome and endosome maturation, Mol. Cell 57 (2015) 207-218, https://doi.org/10.1016/ j.molcel.2014.11.013.

[73] J.A. Martina, Y. Chen, M. Gucek, R. Puertollano, MTORC1 functions as a transcriptional regulator of autophagy by preventing nuclear transport of TFEB, Autophagy. 8 (2012) 903-914, https://doi.org/10.4161/auto.19653.

[74] N. Hosokawa, T. Hara, T. Kaizuka, C. Kishi, A. Takamura, Y. Miura, S. lemura, T. Natsume, K. Takehana, N. Yamada, J.-L. Guan, N. Oshiro, N. Mizushima, Nutrient-dependent mTORC1 association with the ULK1-Atg13-FIP200 complex required for autophagy, Mol. Biol. Cell 20 (2009) 1981-1991, https://doi.org/10.1091/mbc.e08-12-1248.

[75] I.G. Ganley, D.H. Lam, J. Wang, X. Ding, S. Chen, X. Jiang, ULK1.ATG13.FIP200 complex mediates mTOR signaling and is essential for autophagy, J. Biol. Chem. 284 (2009) 12297-12305. doi:https://doi.org/10.1074/jbc. M900573200.

[76] C.H. Jung, C.B. Jun, S.-H. Ro, Y.-M. Kim, N.M. Otto, J. Cao, M. Kundu, D.-H. Kim, ULK-Atg13-FIP200 complexes mediate mTOR signaling to the autophagy machinery, Mol. Biol. Cell 20 (2009) 1992-2003, https://doi.org/10. 1091/mbc.e08-12-1249.

[77] A. Bartolomé, M. Kimura-Koyanagi, S.-I. Asahara, C. Guillén, H. Inoue, K. Teruyama, S. Shimizu, A. Kanno, A. García-Aguilar, M. Koike, Y. Uchiyama, M. Benito, T. Noda, Y. Kido, Pancreatic $\beta$-cell failure mediated by mTORC1 hyperactivity and autophagic impairment, Diabetes. 63 (2014) 2996-3008, https://doi.org/10.2337/db13-0970.

[78] E. Bachar-Wikstrom, J.D. Wikstrom, Y. Ariav, B. Tirosh, N. Kaiser, E. Cerasi, G. Leibowitz, Stimulation of autophagy improves endoplasmic reticulum stress-induced diabetes, Diabetes. 62 (2013) 1227-1237, https://doi.org/10.2337/ db12-1474.

[79] M. Bugliani, S. Mossuto, F. Grano, M. Suleiman, L. Marselli, U. Boggi, P. De Simone, D.L. Eizirik, M. Cnop, P. Marchetti, V. De Tata, Modulation of autophagy influences the function and survival of human pancreatic Beta cells under endoplasmic reticulum stress conditions and in type 2 diabetes, Front. Endocrinol. 10 (2019) 52, https://doi.org/10. 3389/fendo.2019.00052.

[80] H. Lim, Y.-M. Lim, K.H. Kim, Y.E. Jeon, K. Park, J. Kim, H.Y. Hwang, D.J. Lee, H. Pagire, H.J. Kwon, J.H. Ahn, M.-S. Lee, A novel autophagy enhancer as a therapeutic agent against metabolic syndrome and diabetes, Nat. Commun. 9 (2018) 1438, https://doi.org/10.1038/s41467-018-03939-w.

[81] G.-R. Chang, Y.-Y. Wu, Y.-S. Chiu, W.-Y. Chen, J.-W. Liao, H.-M. Hsu, T.-H. Chao, S.-W. Hung, F.C. Mao, Long-term administration of rapamycin reduces adiposity, but impairs glucose tolerance in high-fat diet-fed KK/HIJ mice, Basic Clin. Pharmacol. Toxicol. 105 (2009) 188-198, https://doi. org/10.1111/j.1742-7843.2009.00427.x.

[82] M. Tanemura, Y. Ohmura, T. Deguchi, T. Machida, R. Tsukamoto, H. Wada, S. Kobayashi, S. Marubashi, H. Eguchi, T. Ito, H. Nagano, M. Mori, Y. Doki, Rapamycin causes upregulation of autophagy and impairs islets function both in vitro and in vivo, Am. J. Transplant. Off. J. Am. Soc. Transplant. Am. Soc. Transpl. Surg. 12 (2012) 102-114, https://doi.org/10.1111/j.1600-6143.2011.03771.x. 
[83] A.D. Barlow, M.L. Nicholson, T.P. Herbert, Evidence for rapamycin toxicity in pancreatic $\beta$-cells and a review of the underlying molecular mechanisms, Diabetes. 62 (2013) 2674-2682, https://doi.org/10.2337/db13-0106.

[84] M. Blandino-Rosano, R. Barbaresso, M. JimenezPalomares, N. Bozadjieva, J.P. Werneck-de-Castro, M. Hatanaka, R.G. Mirmira, N. Sonenberg, M. Liu, M.A. Rüegg, M.N. Hall, E. Bernal-Mizrachi, Loss of mTORC1 signalling impairs $\beta$-cell homeostasis and insulin processing, Nat. Commun. 8 (2017) 16014, https://doi.org/10.1038/ ncomms16014.

[85] J.A. Rodríguez-Navarro, L. Rodríguez, M.J. Casarejos, R. M. Solano, A. Gómez, J. Perucho, A.M. Cuervo, J. García de Yébenes, M.A. Mena, Trehalose ameliorates dopaminergic and tau pathology in parkin deleted/tau overexpressing mice through autophagy activation, Neurobiol. Dis. 39 (2010) 423-438, https://doi.org/10.1016/..nbd.2010.05.014.

[86] S. Sarkar, J.E. Davies, Z. Huang, A. Tunnacliffe, D.C. Rubinsztein, Trehalose, a novel mTOR-independent autophagy enhancer, accelerates the clearance of mutant huntingtin and alpha-synuclein, J. Biol. Chem. 282 (2007) 5641-5652, https://doi.org/10.1074/jbc.M609532200.

[87] T. Kaizuka, H. Morishita, Y. Hama, S. Tsukamoto, T. Matsui, Y. Toyota, A. Kodama, T. Ishihara, T. Mizushima, N. Mizushima, An Autophagic flux probe that releases an internal control, Mol. Cell 64 (2016) 835-849, https://doi.org/ 10.1016/j.molcel.2016.09.037.

[88] Y. Jiang, W. Huang, J. Wang, Z. Xu, J. He, X. Lin, Z. Zhou, J. Zhang, Metformin plays a dual role in MIN6 pancreatic $\beta$ cell function through AMPK-dependent autophagy, Int. J. Biol. Sci. 10 (2014) 268-277, https://doi.org/10.7150/ijbs.7929.

[89] S.W. Lim, L. Jin, J. Jin, C.W. Yang, Effect of Exendin-4 on autophagy clearance in Beta cell of rats with tacrolimusinduced diabetes mellitus, Sci. Rep. 6 (2016) 29921, https:// doi.org/10.1038/srep29921.

[90] J. Wang, J. Wu, H. Wu, X. Liu, Y. Chen, J. Wu, C. Hu, D. Zou, Liraglutide protects pancreatic $\beta$-cells against free fatty acids in vitro and affects glucolipid metabolism in apolipoprotein $\mathrm{E}-/-$ mice by activating autophagy, Mol. Med. Rep. 12 (2015) 4210-4218, https://doi.org/10.3892/mmr.2015.3944.

[91] J. Jing Yin, Y. Bo Li, M. Ming Cao, Y. Wang, Liraglutide improves the survival of INS-1 cells by promoting macroautophagy, Int. J. Endocrinol. Metab. 11 (2013) 184-190, https://doi.org/10.5812/ijem.8088.

[92] L. Liu, J. Liu, X. Yu, Dipeptidyl peptidase-4 inhibitor MK-626 restores insulin secretion through enhancing autophagy in high fat diet-induced mice, Biochem. Biophys. Res. Commun. 470 (2016) 516-520, https://doi.org/10.1016/j.bbrc. 2016.01.116.

[93] C.-W. Cheng, V. Villani, R. Buono, M. Wei, S. Kumar, O.H. Yilmaz, P. Cohen, J.B. Sneddon, L. Perin, V.D. Longo, Fasting-Mimicking Diet Promotes Ngn3-Driven $\beta$-Cell Regeneration to Reverse Diabetes, Cell. 168 (2017) 775-788. e12. doi:https://doi.org/10.1016/j.cell.2017.01.040.

[94] K.D. Hall, T. Bemis, R. Brychta, K.Y. Chen, A. Courville, E.J. Crayner, S. Goodwin, J. Guo, L. Howard, N.D. Knuth, B.V. Miller, C.M. Prado, M. Siervo, M.C. Skarulis, M. Walter, P.J. Walter, L. Yannai, Calorie for calorie, dietary fat restriction results in more body fat loss than carbohydrate restriction in people with obesity, Cell Metab. 22 (2015) 427-436, https:// doi.org/10.1016/j.cmet.2015.07.021.

[95] H. Liu, A. Javaheri, R.J. Godar, J. Murphy, X. Ma, N. Rohatgi, J. Mahadevan, K. Hyrc, P. Saftig, C. Marshall, M.L. McDaniel, M.S. Remedi, B. Razani, F. Urano, A. Diwan,
Intermittent fasting preserves beta-cell mass in obesityinduced diabetes via the autophagy-lysosome pathway, Autophagy. 13 (2017) 1952-1968, https://doi.org/10.1080/ 15548627.2017.1368596.

[96] J. Zeng, O.S. Shirihai, M.W. Grinstaff, Degradable Nanoparticles Restore Lysosomal $\mathrm{pH}$ and Autophagic Flux in Lipotoxic Pancreatic Beta Cells, Adv. Healthc. Mater. (2019) e1801511. doi:https://doi.org/10.1002/adhm. 201801511

[97] K.M. Trudeau, A.H. Colby, J. Zeng, G. Las, J.H. Feng, M.W. Grinstaff, O.S. Shirihai, Lysosome acidification by photoactivated nanoparticles restores autophagy under lipotoxicity, J. Cell Biol. 214 (2016) 25-34, https://doi.org/10.1083/ jcb.201511042.

[98] W.E. Balch, J.M. McCaffery, H. Plutner, M.G. Farquhar, Vesicular stomatitis virus glycoprotein is sorted and concentrated during export from the endoplasmic reticulum, Cell. 76 (1994) 841-852.

[99] C.J. Rhodes, P.A. Halban, Newly synthesized proinsulin/ insulin and stored insulin are released from pancreatic B cells predominantly via a regulated, rather than a constitutive, pathway, J. Cell Biol. 105 (1987) 145-153, https://doi. org/10.1083/jcb.105.1.145.

[100] D.L. Curry, L.L. Bennett, G.M. Grodsky, Dynamics of insulin secretion by the perfused rat pancreas, Endocrinology. 83 (1968) 572-584, https://doi.org/10.1210/endo-83-3-572.

[101] L. Orci, M. Ravazzola, M. Amherdt, C. Yanaihara, N. Yanaihara, P. Halban, A.E. Renold, A. Perrelet, Insulin, not C-peptide (proinsulin), is present in crinophagic bodies of the pancreatic B-cell, J. Cell Biol. 98 (1984) 222-228.

[102] P.A. Halban, C.B. Wollheim, Intracellular degradation of insulin stores by rat pancreatic islets in vitro. An alternative pathway for homeostasis of pancreatic insulin content, J. Biol. Chem. 255 (1980) 6003-6006.

[103] P. Meda, Lysosomes in normal pancreatic beta cells, Diabetologia. 14 (1978) 305-310.

[104] L. Boquist, Intracellular digestion and structural variations of secretory granules in pancreatic islet -cells. An ultrastructural study on diabetic and non-diabetic rodents, Horm. Metab. Res. Horm. Stoffwechselforschung Horm. Metab. 2 (1970) 166-171. doi:https://doi.org/10.1055/s-0028-1095088.

[105] D.P. Cameron, W. Stauffacher, L. Orci, M. Amherdt, A.E. Renold, Defective immunoreative insulin secretion in the Acomys cahirinus, Diabetes. 21 (1972) 1060-1071, https:// doi.org/10.2337/diab.21.11.1060.

[106] A. Andersson, J. Westman, C. Hellerström, Effects of glucose on the ultrastructure and insulin biosynthesis of isolated mouse pancreatic islets maintained in tissue culture, Diabetologia. 10 (1974) 743-753.

[107] G. Bommer, H.J. Schäfer, G. Klöppel, Morphologic effects of diazoxide and diphenylhydantoin on insulin secretion and biosynthesis in B cells of mice, Virchows Arch. A Pathol. Anat. Histol. 371 (1976) 227-241.

[108] W. Creutzfeldt, C. Creutzfeldt, H. Frerichs, E. Perings, K. Sicklinger, The morphological substrate of the inhibition of insulin secretion by diazoxide, Horm. Metab. Res. Horm. Stoffwechselforschung Horm. Metab. 1 (1969) 53-64, https://doi.org/10.1055/s-0028-1095173.

[109] P.A. Halban, C.B. Wollheim, B. Blondel, A.E. Renold, Longterm exposure of isolated pancreatic islets to mannoheptulose: evidence for insulin degradation in the beta cell, Biochem. Pharmacol. 29 (1980) 2625-2633.

[110] G. Klöppel, E. Ruttmann, G. Bommer, H.J. Schäfer, [Crinophagy and insulin secretion. B cell morphology after 
various inhibition of insulin secretion (author's transl)], Verh. Dtsch. Ges. Pathol. (1976) 220-224.

[111] B.P. Richardson, L. Turcot-Lemay, M.L. McDaniel, P.E. Lacy, Pancreatic beta cell changes induced by cyproheptadine in vitro, Lab. Investig. J. Tech. Methods Pathol. 33 (1975) 509-513.

[112] E. Van Obberghen, G. Somers, G. Devis, M. Ravazzola, F. Malaisse-Lagae, L. Orci, W.J. Malaisse, Dynamics of insulin release and microtubular-microfilamentous system. VI. Effect of D2O, Endocrinology. 95 (1974) 1518-1528. doi: https://doi.org/10.1210/endo-95-6-1518.

[113] R. Zwahlen, B.P. Richardson, R.E. Hauser, The production and elimination of myeloid bodies by cultured pancreatic islet cells, J. Ultrastruct. Res. 67 (1979) 340-356.

[114] P.M. Dean, Ultrastructural morphometry of the pancreatic -cell, Diabetologia. 9 (1973) 115-119.

[115] A.H. Schnell, L.A. Borg, Lysosomes and pancreatic islet function. Glucose-dependent alterations of lysosomal morphology, Cell Tissue Res. 239 (1985) 537-545.

[116] P.A. Halban, A.E. Renold, Influence of glucose on insulin handling by rat islets in culture. A reflection of integrated changes in insulin biosynthesis, release, and intracellular degradation, Diabetes. 32 (1983) 254-261. doi:https://doi. org/10.2337/diab.32.3.254.

[117] A. Goginashvili, Z. Zhang, E. Erbs, C. Spiegelhalter, P. Kessler, M. Mihlan, A. Pasquier, K. Krupina, N. Schieber, L. Cinque, J. Morvan, I. Sumara, Y. Schwab, C. Settembre, R. Ricci, Insulin granules. Insulin secretory granules control autophagy in pancreatic $\beta$ cells, Science. 347 (2015) 878-882, https://doi.org/10.1126/science.aaa2628.

[118] J. Kim, M. Kundu, B. Viollet, K.L. Guan, AMPK and mTOR regulate autophagy through direct phosphorylation of Ulk1, Nat. Cell Biol. 13 (2011) 132-U71, https://doi.org/10.1038/Ncb2152.

[119] R. Hatakeyama, M.-P. Péli-Gulli, Z. Hu, M. Jaquenoud, G. M. Garcia Osuna, A. Sardu, J. Dengjel, C. De Virgilio, Spatially Distinct Pools of TORC1 Balance Protein Homeostasis, Mol. Cell. 73 (2019) 325-338.e8. doi:https://doi.org/ 10.1016/j.molcel.2018.10.040.

[120] S. Shoji-Kawata, R. Sumpter, M. Leveno, G.R. Campbell, Z. Zou, L. Kinch, A.D. Wilkins, Q. Sun, K. Pallauf, D. MacDuff, C. Huerta, H.W. Virgin, J.B. Helms, R. Eerland, S.A. Tooze, R. Xavier, D.J. Lenschow, A. Yamamoto, D. King, O. Lichtarge, N.V. Grishin, S.A. Spector, D.V. Kaloyanova, B. Levine, Identification of a candidate therapeutic autophagyinducing peptide, Nature. 494 (2013) 201-206, https://doi. org/10.1038/nature11866.

[121] M. Prentki, F.M. Matschinsky, S.R. Madiraju, Metabolic signaling in fuel-induced insulin secretion, Cell Metab. 18 (2013) 162-185, https://doi.org/10.1016/j.cmet.2013.05.018.

[122] G. Gold, M.L. Gishizky, G.M. Grodsky, Evidence that glucose "marks" beta cells resulting in preferential release of newly synthesized insulin, Science. 218 (1982) 56-58.

[123] B.J. Marsh, C. Soden, C. Alarcón, B.L. Wicksteed, K. Yaekura, A.J. Costin, G.P. Morgan, C.J. Rhodes, Regulated autophagy controls hormone content in secretory-deficient pancreatic endocrine beta-cells, Mol. Endocrinol. Baltim. Md. 21 (2007) 2255-2269, https://doi.org/10.1210/me.2007-0077.

[124] Y. Riahi, J.D. Wikstrom, E. Bachar-Wikstrom, N. Polin, H. Zucker, M.-S. Lee, W. Quan, L. Haataja, M. Liu, P. Arvan, E. Cerasi, G. Leibowitz, Autophagy is a major regulator of beta cell insulin homeostasis, Diabetologia. 59 (2016) 1480-1491, https://doi.org/10.1007/s00125-016-3868-9.

[125] S. Yamamoto, K. Kuramoto, N. Wang, X. Situ, M. Priyadarshini, W. Zhang, J. Cordoba-Chacon, B.T.
Layden, C. He, Autophagy differentially regulates insulin production and insulin sensitivity, Cell Rep. 23 (2018) 3286-3299, https://doi.org/10.1016/j.celrep.2018.05. 032.

[126] A. Yamamoto, Y. Tagawa, T. Yoshimori, Y. Moriyama, R. Masaki, Y. Tashiro, Bafilomycin A1 prevents maturation of autophagic vacuoles by inhibiting fusion between autophagosomes and lysosomes in rat hepatoma cell line, H-4-II-E cells, Cell Struct. Funct. 23 (1998) 33-42.

[127] C. Mauvezin, P. Nagy, G. Juhász, T.P. Neufeld, Autophagosome-lysosome fusion is independent of $\mathrm{V}$ ATPase-mediated acidification, Nat. Commun. 6 (2015) 7007, https://doi.org/10.1038/ncomms8007.

[128] Y. Nishida, S. Arakawa, K. Fujitani, H. Yamaguchi, T. Mizuta, T. Kanaseki, M. Komatsu, K. Otsu, Y. Tsujimoto, S. Shimizu, Discovery of Atg5/Atg7-independent alternative macroautophagy, Nature. 461 (2009) 654-658, https://doi. org/10.1038/nature08455.

[129] H. Yamaguchi, S. Arakawa, T. Kanaseki, T. Miyatsuka, Y. Fujitani, H. Watada, Y. Tsujimoto, S. Shimizu, Golgi membraneassociated degradation pathway in yeast and mammals, EMBO J. (2016). doi:10.15252/embj.201593191.

[130] V. Malhotra, F. Campelo, PKD regulates membrane fission to generate TGN to cell surface transport carriers, Cold Spring Harb Perspect Biol. 3 (2011). doi:https://doi.org/10. 1101/cshperspect.a005280.

[131] G. Sumara, I. Formentini, S. Collins, I. Sumara, R. Windak, B. Bodenmiller, R. Ramracheya, D. Caille, H. Jiang, K.A. Platt, P. Meda, R. Aebersold, P. Rorsman, R. Ricci, Regulation of PKD by the MAPK p38delta in insulin secretion and glucose homeostasis, Cell. 136 (2009) 235-248, https://doi.org/10.1016/j.cell.2008.11.018.

[132] H. Gehart, A. Goginashvili, R. Beck, J. Morvan, E. Erbs, I. Formentini, M.A. De Matteis, Y. Schwab, F.T. Wieland, R. Ricci, The BAR domain protein Arfaptin-1 controls secretory granule biogenesis at the trans-Golgi network, Dev. Cell 23 (2012) 756-768, https://doi.org/10.1016/j.devcel.2012.07.019.

[133] S.S. Hussain, M.T. Harris, A.J.B. Kreutzberger, C.M. Inouye, C.A. Doyle, A.M. Castle, P. Arvan, J.D. Castle, Control of insulin granule formation and function by the $A B C$ transporters $A B C G 1$ and $A B C A 1$ and by oxysterol binding protein OSBP, Mol. Biol. Cell 29 (2018) 1238-1257, https:// doi.org/10.1091/mbc.E17-08-0519.

[134] A. Hausser, S. Märtens, G. Link, K. Pfizenmaier, P. Storz, A. Toker, Protein kinase $D$ regulates vesicular transport by phosphorylation and activation of phosphatidylinositol-4 kinase III $\beta$ at the Golgi complex, Nat. Cell Biol. 7 (2005) 880-886, https://doi.org/10.1038/ncb1289.

[135] T.R. Graham, C.G. Burd, Coordination of Golgi functions by phosphatidylinositol 4-kinases, Trends Cell Biol. 21 (2011) 113-121, https://doi.org/10.1016/j.tcb.2010.10.002.

[136] M.A. De Matteis, C. Wilson, G. D'Angelo, Phosphatidylinositol-4-phosphate: the Golgi and beyond, BioEssays News Rev. Mol. Cell. Dev. Biol. 35 (2013) 612-622, https://doi.org/10.1002/bies.201200180.

[137] D. Cruz-Garcia, M. Ortega-Bellido, M. Scarpa, J. Villeneuve, M. Jovic, M. Porzner, T. Balla, T. Seufferlein, V. Malhotra, Recruitment of arfaptins to the trans-Golgi network by $\mathrm{PI}(4) \mathrm{P}$ and their involvement in cargo export, EMBO J. 32 (2013) 1717-1729, https://doi.org/10.1038/ emboj.2013.116.

[138] X. Zhang, S. Jiang, K.A. Mitok, L. Li, A.D. Attie, T.F.J. Martin, BAIAP3, a C2 domain-containing Munc13 protein, controls the fate of dense-core vesicles in neuroendocrine 
cells, J. Cell Biol. 216 (2017) 2151-2166, https://doi.org/10. 1083/jcb.201702099.

[139] G.S. Hotamisligil, Inflammation, metaflammation and immunometabolic disorders, Nature. 542 (2017) 177-185, https:// doi.org/10.1038/nature21363.

[140] M.Y. Donath, M. Böni-Schnetzler, H. Ellingsgaard, J.A. Ehses, Islet inflammation impairs the pancreatic beta-cell in type 2 diabetes, Physiol. Bethesda Md. 24 (2009) 325-331, https://doi.org/10.1152/physiol.00032.2009.

[141] S.H. Back, R.J. Kaufman, Endoplasmic reticulum stress and type 2 diabetes, Annu. Rev. Biochem. 81 (2012) 767-793, https://doi.org/10.1146/annurev-biochem-072909-095555.

[142] R.P. Robertson, J. Harmon, P.O.T. Tran, V. Poitout, Betacell glucose toxicity, lipotoxicity, and chronic oxidative stress in type 2 diabetes, Diabetes. 53 (Suppl. 1) (2004) S119-S124, https://doi.org/10.2337/diabetes.53.2007. s119.

[143] A.M. Cuervo, S.R. Terlecky, J.F. Dice, E. Knecht, Selective binding and uptake of ribonuclease a and glyceraldehyde-3phosphate dehydrogenase by isolated rat liver lysosomes, J. Biol. Chem. 269 (1994) 26374-26380.

[144] J.L. Schneider, Y. Suh, A.M. Cuervo, Deficient chaperonemediated autophagy in liver leads to metabolic dysregulation, Cell Metab. 20 (2014) 417-432, https://doi.org/10. 1016/j.cmet.2014.06.009. 